\title{
Article \\ Late Quaternary Marine Terraces and Tectonic Uplift Rates of the Broader Neapolis Area (SE Peloponnese, Greece)
}

\author{
Efthimios Karymbalis ${ }^{1, *}{ }^{\circledR}$, Konstantinos Tsanakas ${ }^{1}{ }^{\mathbb{D}}$, Ioannis Tsodoulos ${ }^{1,2}$, Kalliopi Gaki-Papanastassiou ${ }^{3}$, \\ Dimitrios Papanastassiou ${ }^{4}$, Dimitrios-Vasileios Batzakis ${ }^{1}$ (D) and Konstantinos Stamoulis ${ }^{2}$ (D) \\ 1 Department of Geography, Harokopio University, 70 El. Venizelou Str., GR-17671 Athens, Greece; \\ ktsanakas@hua.gr (K.T.); itsodoul@cc.uoi.gr (I.T.); mpatzakis@hua.gr (D.-V.B.) \\ 2 Department of Physics, University of Ioannina, GR-45110 Ioannina, Greece; kstamoul@cc.uoi.gr \\ 3 Department of Geography and Climatology, Faculty of Geology \& Geoenvironment, \\ National and Kapodistrian University of Athens, GR-15784 Athens, Greece; gaki@geol.uoa.gr \\ 4 Institute of Geodynamics, National Observatory of Athens, GR-11810 Athens, Greece; d.papan@noa.gr \\ * Correspondence: karymbalis@hua.gr; Tel.: +30-210-9549159
}

check for updates

Citation: Karymbalis, E.; Tsanakas, K.; Tsodoulos, I.; Gaki-Papanastassiou, K. Papanastassiou, D.; Batzakis, D.-V.; Stamoulis, K. Late Quaternary Marine Terraces and Tectonic Uplift Rates of the Broader Neapolis Area (SE Peloponnese, Greece). J. Mar. Sci. Eng. 2022, 10, 99. https://doi.org/ 10.3390/jmse10010099

Academic Editor: Antoni Calafat

Received: 19 December 2021

Accepted: 8 January 2022

Published: 12 January 2022

Publisher's Note: MDPI stays neutral with regard to jurisdictional claims in published maps and institutional affiliations.

Copyright: (C) 2022 by the authors. Licensee MDPI, Basel, Switzerland. This article is an open access article distributed under the terms and conditions of the Creative Commons Attribution (CC BY) license (https:// creativecommons.org/licenses/by/ $4.0 /)$.

\begin{abstract}
Marine terraces are geomorphic markers largely used to estimate past sea-level positions and surface deformation rates in studies focused on climate and tectonic processes worldwide. This paper aims to investigate the role of tectonic processes in the late Quaternary evolution of the coastal landscape of the broader Neapolis area by assessing long-term vertical deformation rates. To document and estimate coastal uplift, marine terraces are used in conjunction with Optically Stimulated Luminescence (OSL) dating and correlation to late Quaternary eustatic sea-level variations. The study area is located in SE Peloponnese in a tectonically active region. Geodynamic processes in the area are related to the active subduction of the African lithosphere beneath the Eurasian plate. A series of 10 well preserved uplifted marine terraces with inner edges ranging in elevation from $8 \pm 2 \mathrm{~m}$ to $192 \pm 2 \mathrm{~m}$ above m.s.l. have been documented, indicating a significant coastal uplift of the study area. Marine terraces have been identified and mapped using topographic maps (at a scale of 1:5000), aerial photographs, and a $2 \mathrm{~m}$ resolution Digital Elevation Model (DEM), supported by extensive field observations. OSL dating of selected samples from two of the terraces allowed us to correlate them with late Pleistocene Marine Isotope Stage (MIS) sea-level highstands and to estimate the long-term uplift rate. Based on the findings of the above approach, a long-term uplift rate of $0.36 \pm 0.11 \mathrm{~mm} \mathrm{a}^{-1}$ over the last $401 \pm 10 \mathrm{ka}$ has been suggested for the study area. The spatially uniform uplift of the broader Neapolis area is driven by the active subduction of the African lithosphere beneath the Eurasian plate since the study area is situated very close $(\sim 90 \mathrm{~km})$ to the active margin of the Hellenic subduction zone.
\end{abstract}

Keywords: geomorphology; marine terraces; sea-level indicators; tectonic uplift; Quaternary; OSL dating; Elafonissos Island; Greece

\section{Introduction}

Coastal regions above subduction zones are of great interest for studying the active tectonic processes at convergent plate boundaries, especially if the presence of suitable geomorphic markers allows quantifying the deformation of the upper plate [1-4]. Among such geomorphic markers are palaeoshoreline indicators (beach rocks, marine notches, marine terraces, and palaeo-strandlines) which indicate the former positions of shorelines and are commonly used to determine rates and patterns of long-term rock uplift and deformation in tectonically active settings [1,5-12].

Marine terraces are palaeo-platforms of marine origin that formed at the coast as relatively flat and generally smooth surfaces that dip gently seaward [13]. They are most commonly observed in regions that are tectonically uplifting. These landforms are prominent along many coastlines, and they can be useful for measuring rates and patterns of 
tectonic uplift. A marine terrace typically consists of two distinct surfaces: an abrasion ramp dipping gently seaward and an inland-bounding sea-cliff dipping seaward. The junction between the roughly flat paleo-platform and its internal palaeo-cliff is called the palaeoshoreline angle (also called the inner edge of the platform), and it is here that a wave-cut notch may be preserved [13]. The inner edge represents a marker that closely approximates the elevation of the local sea level at the time of terrace formation, typically during sea-level highstands [1,14-16]. Hence this feature is an important palaeohorizontal indicator that permits the assessment of spatial variations in vertical motions of the crust [13].

The occurrence of a flight of marine terraces (a sequence of marine terraces with step-like morphology) in a coastal region is the result of the interaction between longterm tectonic uplift and Quaternary cyclic sea-level fluctuations, associated with global climatic changes $[1,6,17-21]$. Quaternary cyclic sea-level changes are typically represented by eustatic (global) curves derived from the Oxygen isotope ratios [22-25]. These curves show a cyclic trend characterized by peaks corresponding to distinct marine interglacial highstands, represented by the odd-numbered Marine Isotope Stages (MIS), and marine glacial lowstands, indicated by the even-numbered MIS [26]. Paleoplatforms are thought to form during periods of relative sea-level stability (e.g., when the rates of rock uplift and sealevel change balance each other) and are abandoned following sea-level highstands $[1,5,6,8]$.

The study of marine terraces started in the 1970s in several places of the world and has since expanded to almost all the uplifting coastal regions [1]. The hypothesis that the mean uplift rate during the late Pleistocene is high enough to preserve the marine terraces permitted the dating of the terrace sequences and the evaluation of the uplift history of several raised coastal regions worldwide [7,18,27-30]. The progress achieved is owed, to a great extent, to both the establishment of the theory of the Pleistocene eustatic sea-level fluctuations and the development of accurate dating techniques. It is obvious that to accurately evaluate vertical movements of coastal regions affected by Quaternary tectonic uplift, appropriate age constraints for marine terraces are required.

The age of a marine terrace can be estimated through various dating methods. For very recent marine terraces, ${ }^{14} \mathrm{C}$ dating has been used to determine the age of emplacement of certain markers. Among the absolute dating methods of marine terraces, U-Th disequilibrium provides the least ambiguous one, but the presence of suitable fossils is required. Other, less precise dating methods also rely on scarce fossil material, e.g., amino acid racemization, $\mathrm{d}^{18} \mathrm{O}$ stratigraphy, and faunal assemblage correlations [20]. When organic remains are generally absent, Optically Stimulated Luminescence (OSL) dating methods can be applied to determine the ages of the marine terrace deposits [8,21,28,31,32]. Another dating method that has great potential for constraining the age of Pleistocene marine bedrock terraces is surface exposure dating, which is based on the analysis of in situ-produced cosmogenic nuclides such as ${ }^{10} \mathrm{Be},{ }^{21} \mathrm{Ne},{ }^{26} \mathrm{Al}$, or ${ }^{36} \mathrm{Cl}$ in near-surface rocks $[11,33,34]$. Cosmogenic radionuclides (CRNs) produced in situ in the terrace cover deposits provide a relatively new tool for dating marine terraces [35] because ${ }^{10} \mathrm{Be}$ and ${ }^{26} \mathrm{Al}$ accumulation in quartz acts as a clock [36]. On flights of terraces where only one terrace can be dated, steady uplift is often assumed, and the altitudinal spacing of the terraces is used to assign sea-level highstand ages [5-7,37].

In Greece, marine terraces are observed in various places such as the southern coasts of the Gulf of Corinth (the Corinth Rift) and several coastal regions along the emergent fore-arc of the Hellenic Subduction Zone, including the southwestern Peloponnese and the islands of Cephalonia, Kythera, Crete, Karpathos, and Rhodes [6,10,29,30,38-42]. The flight of marine terraces along the southern coast of the Gulf of Corinth, an intracontinental rift in Central Greece, has attracted considerable scientific interest since it is one of the fastest extending regions accessible on land worldwide [6,11,29,42-47]. Another wellstudied area is the island of Crete, which lies along the emergent fore-arc of the Hellenic Subduction Zone. Cretan paleo-shorelines have been extensively used to determine the 
spatial and temporal pattern of Quaternary uplift and explain the mechanisms of fore-arc deformation $[4,8-10,20,48-50]$.

This study aims to provide information about the long-term landscape evolution of the broader area of Neapolis, in southeastern Peloponnese, Greece, in response to tectonic uplift during the late Quaternary. For this purpose, a series of ten uplifted marine terraces, which represent former shorelines, have been identified and mapped in detail through Geographic Information System (GIS) techniques and extensive fieldwork, and selected samples from sediments of two marine terraces have been collected and dated using the OSL technique. Marine terraces have long been recognized in the study area by previous authors [51-54] but have received little attention so far, and their dating and distribution, both in space and time, has never been successfully attempted before. The study of this outstandingly wellpreserved flight of marine terraces provides important information on the Quaternary uplift history, as well as on the process governing orogenesis and landscape evolution, which remains poorly understood for the study area. Age determination of two of the marine terraces allowed us to correlate their inner edges to past sea-level highstands $[25,26,55]$, and in this way to estimate the long-term tectonic uplift rate for the study area over the last $401 \pm 10 \mathrm{ka}$.

\section{Study Area}

The study area is located along the southeastern coast of the Lakonic Gulf in southeast Peloponnese and lies between cape Koulenti to the northwest, and Agia Marina, to the southeast (Figure 1). It also includes Elafonissos, a small island with an area of $19 \mathrm{~km}^{2}$ separated from the mainland by a $1 \mathrm{~km}$ wide and $2.5 \mathrm{~m}$ deep canal of seawater [56]. It is a tectonically active area since it is the easternmost terrestrial part of the southwestern Aegean fore-arc, situated approximately $90 \mathrm{~km}$ east-northeast of the Hellenic Subduction Zone where the African tectonic plate is subducting beneath the Eurasian plate at a mean rate of $\sim 36 \mathrm{~mm} \mathrm{a}^{-1}[57,58]$. Rates of crustal motion offshore the Peloponnese and Crete Island with respect to Africa, estimated from GPS measurements, are up to $\sim 40 \mathrm{~mm} \mathrm{a}^{-1}[59,60]$. Earthquakes, seismic tomography, and seismic reflection data reveal that the Hellenic Subduction Zone is the largest, fastest, and most seismically active subduction zone in the Mediterranean [61,62]. Seismic tomography has imaged the subducted slab to depths $>600 \mathrm{~km}[61,63]$, whereas Mesozoic to Cenozoic arc volcanism [64] from the eastern Mediterranean and the Aegean show that the Hellenic Subduction Zone has continued to consume the African plate since at least $100 \mathrm{Ma}[65,66]$. Hence, the geodynamic processes in the region are related to the active convergent plate boundary, and the study area provides an example of actively deforming continental crust situated in the fore-arc of a subduction zone (Figure 1a). 


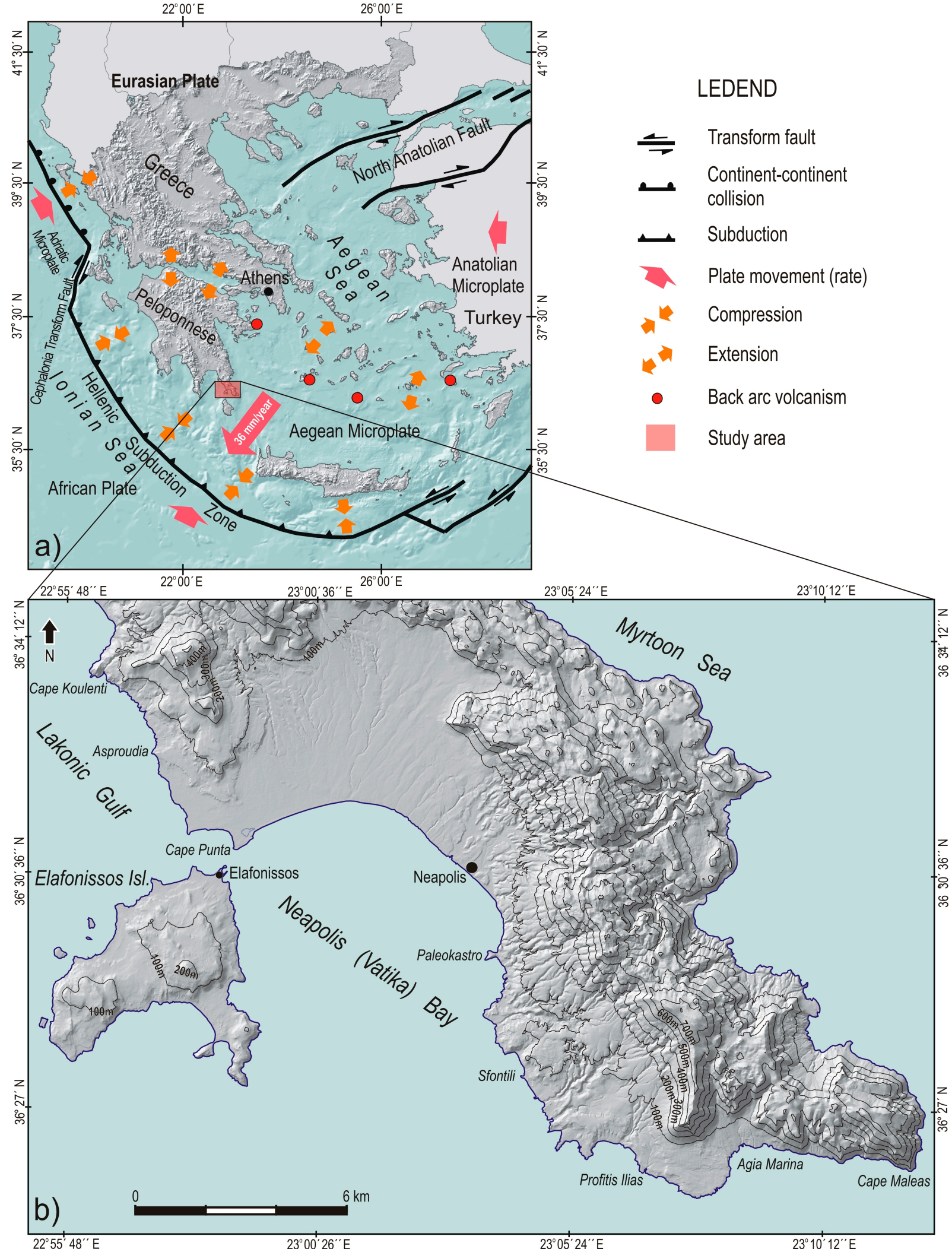

Figure 1. (a) The geotectonic setting of Greece (modified from Reilinger et al. [58], and Vott et al. [67]) depicting the location of the study area and (b) hill shaded map of the study area produced from topographic maps at 1:5000 scale of the Hellenic Military Geographical Service. 
The Mesozoic basement of the study area consists of geological formations of the geotectonic units of Gavrovo-Tripolis and Olonos-Pindos and a unit of phyllites-quartzites (Figure 2). The Olonos-Pindos unit crops out in a very small part of the study area and consists of tectonized radiolarites and limestones of the Triassic to Eocene age [68,69]. The geotectonic unit of Tripolis is represented by Upper Triassic to Eocene dolomites, limestones, and dolomitic limestones, whereas its lower parts consist of very low-grade metamorphic formations (mainly clastic and carbonate rocks) of Triassic age (Tyros beds) (Figure 2). A relatively extensive part of the broader Neapolis area consists of a series of highly metamorphosed rocks consisting of phyllites, quartzites, as well as calcitic and dolomitic marbles of Permian-Triassic age [68,69]. The Alpine basement is overlain by extensive outcrops of Pliocene and Pleistocene deposits (Figure 2). The occurrence of Pliocene-Pleistocene sedimentary sequences of marine origin up to $\sim 180 \mathrm{~m}$ above presentday sea level is the most evident consequence of the widespread Quaternary uplift of the study area due to its proximity to the Hellenic Subduction Zone. Upper Pliocene to lower Pleistocene formations are composed of marine deposits, which are mainly pelites, sandstones, conglomerates, calcarenites, and carbonate rocks with red algae $[54,68,69]$. On top of the phyllites-quartzites unit, a series of Pleistocene formations of fluvio-terrestrial origin (clays, sands, loams, and angular rock fragments) occurs [51,68,69]. The Holocene deposits consist of talus cones, scree, and unconsolidated alluvial deposits, eluvial mantle materials, whereas coastal sand dunes are observed along the north, northwest, and south shoreline of Elafonissos Island and along the coast east of Cape Punta [56].

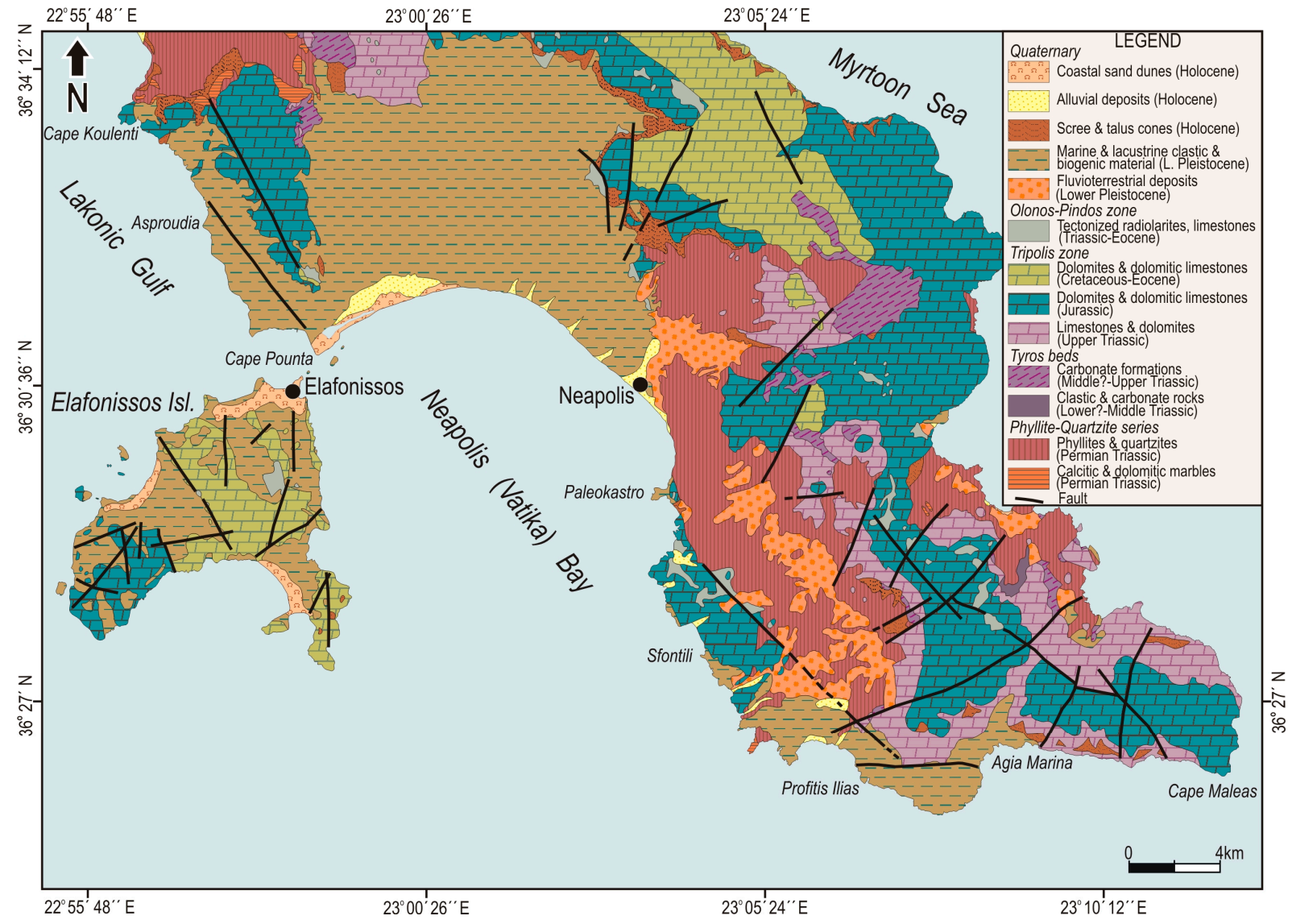

Figure 2. Geological map of the study area modified from Theodoropoulos [51], IGME [68], and Lekkas et al. [69]. Fault kinematics are undifferentiated, and most faults are inactive.

Previous researches led to the identification of uplifted marine terraces carved into the pre-existing Pliocene-Pleistocene formations and limestone bedrock at several locations in the study area. Theodoropoulos [51] reported 3 relatively flat surfaces at an elevation 
between 10 and $140 \mathrm{~m}$ above mean sea level (m.s.l.). According to him, the 2 lower (at 10-15 $\mathrm{m}$ and 25-30 m, respectively) correspond to marine terraces of the Tyrrhenian age.

A sequence of 5 uplifted marine terraces and remnants of uplifted marine abrasion platforms, ranging in elevation from $4 \mathrm{~m}$ to approximately $140 \mathrm{~m}$, mainly carved into the Pliocene-Pleistocene formations, have been recognized by Kelletat et al. [52] at the broader area of Neapolis, Profitis Ilias, and Agia Marina. According to the same authors, there is a sudden southward inclination and submergence of the older marine surfaces, whereas the altitudes of the terraces on the Elafonissos Island are higher than on the opposite mainland.

Lekkas et al. [53] noted the presence of 3 relatively continuous marine terraces from 6 to $55 \mathrm{~m}$ in elevation, as well as several non-continuous higher marine terrace surfaces, up to $120 \mathrm{~m}$, on the Elafonissos Island. Some of the uplifted marine terraces of the island cut into Pleistocene sedimentary formations, but there are also surfaces carved into the limestone bedrock.

The general trend of the faults in the study area is mainly northwest-southeast, with some secondary ones having a northeast-southwest direction (Figure 2). Most of these faults are impossible to distinguish on the hill-shaded map, indicating that they are inactive.

\section{Materials and Methods}

\subsection{Mapping}

To correlate the marine terraces of the study area in space and time, the first step was the detailed mapping of the distinct marine terrace surfaces and their inner edges (the palaeoshoreline angle of each palaeo-platform). Mapping was carried out using both Geographic Information System (GIS) and field techniques [40,70,71]. A GIS spatial geodatabase including various thematic layers (contour lines of $4 \mathrm{~m}$, and $2 \mathrm{~m}$ or even $1 \mathrm{~m}$ in gently sloping areas, elevation points, and drainage network) was organized and implemented using Esri ArcGIS software. The main sources of these data were detailed analog topographic maps at 1:5000 scale, obtained from the Hellenic Military Geographical Service. The projection system was the Hellenic Geodetic Reference System 1987 (HGRS'87). GIS procedures produced secondary layers including a raster $2 \mathrm{~m}$ cell size DEM of the study area (to generate the DEM, the TOPOGRID algorithm in ArcGIS was used), a hill-shade map, a slope-aspect map, a range map, and a map of morphological discontinuities of slopes. Additionally, land surface parameters such as slope, gradient, aspect, curvature, and roughness were calculated. These derivatives, along with the above thematic maps and visual inspection and interpretation of georeferenced aerial photo mosaic (made from aerial photos taken by the Hellenic Military Geographical Service in 1996) and recent Google Earth Pro images, were particularly useful in identifying, delineating, and mapping the uplifted marine terraces of the study area. In this way, preliminary morphological sketches depicting marine terraces' surfaces and their inner edges (when possible) were produced in the form of printed paper maps at the scale of 1:5000, suitable for the field survey.

The field survey focused upon the spatial arrangement of the uplifted abrasion platforms and the accuracy of the inner edges' elevations at specific locations. Field control was necessary to correct and validate marine terraces' maps/sketches drawn from the DEM analysis and aerial photos and Google Earth Pro images interpretation. The entire study area was investigated, verifying most of the uplifted marine terraces identified during the previous lab mapping phase. Where possible, a handheld Topcon GMS-2 Differential Global Positioning System (DGPS) was used to mark waypoints for the precise location of the inner edges that represent former shorelines. The accuracy of the DGPS used is considered to be suitable for 1:5000 scale field surveys. During the post-field survey mapping phase, the existing GIS database was integrated with the DGPS data, and a comparison of field and remote sensing mapping data took place to validate the initial map of the marine terraces sequence and proceed to the production of the final marine terraces map. The final map depicts a series of ten well-defined marine terraces grouped according to the elevation ranges of their inner edges. 
To verify the elevation of the different terraces and their inner edges, three topographic profiles, one for each locality of the study area, were drawn across the terraces, perpendicular to the coastline. The profiles are based on the $2 \mathrm{~m} \mathrm{DEM}$, while the inner shoreline angle elevations of the different marine terraces along the lines of the topographic profiles were measured in the field using the DGPS equipment.

\subsection{Optically Stimulated Luminescence (OSL) Dating}

To correlate the marine terraces in space and time, two sedimentary block samples, designated as $\mathrm{M}$ and $\mathrm{N}$, were collected from the caprock outcrops of two different terraces for OSL dating. The samples were collected at the locations of the topographic profiles 1 and 3, as close as possible to the marine terraces' inner edges. Sediments deposited in shallow marine conditions have a high chance of complete bleaching before burial [72,73]. The OSL samples were referenced by handheld DGPS, sealed, and then transported to the Nuclear Physics Laboratory, Department of Physics, University of Ioannina, Ioannina, Greece, for luminescence dating.

The outer $\sim 3 \mathrm{~cm}$ from each of the 10-15 cm-sized sedimentary block samples was discarded, under dim red light, and then divided into 2 parts for the equivalent dose (ED) and annual dose (AD) analysis. The ED sub-samples were subjected to wet-sieving to obtain the 100-150 $\mu \mathrm{m}$ fractions, from which purified quartz grains were obtained by standard laboratory procedures [74]. The purity of the extracted quartz grains was checked using the OSL-IR depletion ratio [75]. The chemically purified quartz grains were mounted on $10 \mathrm{~mm}$ diameter stainless steel discs by covering a part with 3-4 $\mathrm{mm}$ diameter at the center of the disc [76] using acetone suspension. Following sample preparation, the OSL signal from the extracted quartz grains was measured using a Risø TL/OSL-DA-20 reader equipped with blue $(470 \mathrm{~nm})$ LEDs and a $7 \mathrm{~mm}$ Hoya U-340 optical detection filter [77]. The singlealiquot regenerative-dose (SAR) protocol of Murray and Wintle [78] was used to determine all ED values. All OSL measurements were made using stimulation with blue diodes at $125^{\circ} \mathrm{C}$ for $40 \mathrm{~s}$. The OSL signal was calculated using the initial $0.8 \mathrm{~s}$ minus a background from the mean of the last $8 \mathrm{~s}$ of the stimulation curve at $90 \%$ LED power. For all OSL measurements, a preheat temperature of $240{ }^{\circ} \mathrm{C}(10 \mathrm{~s})$ and a cut-heat temperature of $160{ }^{\circ} \mathrm{C}$ $(0 \mathrm{~s})$ were selected after performing a dose recovery-preheat plateau test on a representative sample using different preheat temperatures. Measurements were rejected if recycling ratios exceeded $10 \%$ from unity and recuperation exceeded $5 \%$ of the natural signal.

The AD rate for each sample was calculated from radionuclide concentrations, measured by high-resolution gamma spectrometry, using the conversion factors of Liritzis et al. [79], and calculated using the DRAC software (v1.1; [80]).

\subsection{Rates of Coastal Uplift Estimation and Eustatic Correlations}

It is generally accepted that flights of marine terraces result from the interplay of the rate of eustatic sea-level change and the rate of vertical tectonic motion [13,81-84]. Hence the sequence of uplifted marine terraces observed in the landscape of the study area is assumed to be the geomorphic record of late Quaternary periods of relative sealevel stability such as glacio-eustatic sea-level highstands [1,5], which happened during odd-numbered MIS [1].

Late Pleistocene uplift rates were determined by elevation-age relationships using the following equation $[1,8,28]$ :

$$
\mathrm{U}=(\mathrm{E}-\mathrm{e}) / \mathrm{A},
$$

where $U$ is the uplift rate, $E$ is the present-day elevation of the palaeo-shoreline for a particular terrace, $\mathrm{A}$ is the age of the respective terrace, and e corresponds to the elevation of the sea level at the time of terrace formation.

Since many sea-level curves that show a significant variability of sea-level through time have been derived for different parts of the world $[26,55,85]$, there are some approaches where apparent uplift rates have been calculated by neglecting the eustatic component (e $=0$, e.g., $[3,86,87])$. In this way, errors attributed to past eustatic sea-level positions can 
be discarded by obtaining a relative uplift rate with respect to present-day sea level. In our study, we did not follow this approach since it may introduce a substantial bias [16]. To model the deformation of several different palaeo-horizontal lines, the use of a common reference level is necessary. To refer palaeo-shorelines to the present-day sea level requires corrections. In principle, prominent shorelines that formed during past interglacial periods need corrections because they correspond to sea-level highstands that, in the global record, are likely to be within a few or several meters of the present interglacial. In this paper, we calculate uplift rates by using the eustatic sea-level curve proposed by Waelbroeck et al. [25], which is built from a multitude of different $\delta 18 \mathrm{O}$ records from all around the globe. We chose this curve because it is a good approximation of global eustatic sea-level change since it is a composite relative sea-level curve, over the last four climatic cycles, based on long benthic isotopic records retrieved at one North Atlantic and one Equatorial Pacific site. Moreover, it provides a confidence interval, which in turn is useful to calculate uplift rate errors.

Although Equation (1) is simple, it is difficult to estimate precise long-term uplift rates because of the errors on the different terms involved in it, especially on the eustatic sea-level curve (e) as well as on the accuracy of the elevation measurements of the present-day inner edge of the terrace (E). Therefore, the calculation of a precise uplift rate value is complicated, and we focused on obtaining uplift rate ranges, including the different uncertainties using a modified version of Equation (1) [28] (Figure 3):

$$
\begin{aligned}
& \mathrm{Umin}=[(\mathrm{E}-\Delta \mathrm{E})-(\mathrm{e}+\Delta \mathrm{e})] /(\mathrm{A}+\Delta \mathrm{A}), \\
& \mathrm{Umax}=[(\mathrm{E}+\Delta \mathrm{E})-(\mathrm{e}-\Delta \mathrm{e})] /(\mathrm{A}-\Delta \mathrm{A}),
\end{aligned}
$$

where the delta symbols $(\Delta)$ represent the estimated variability in the different parameters.

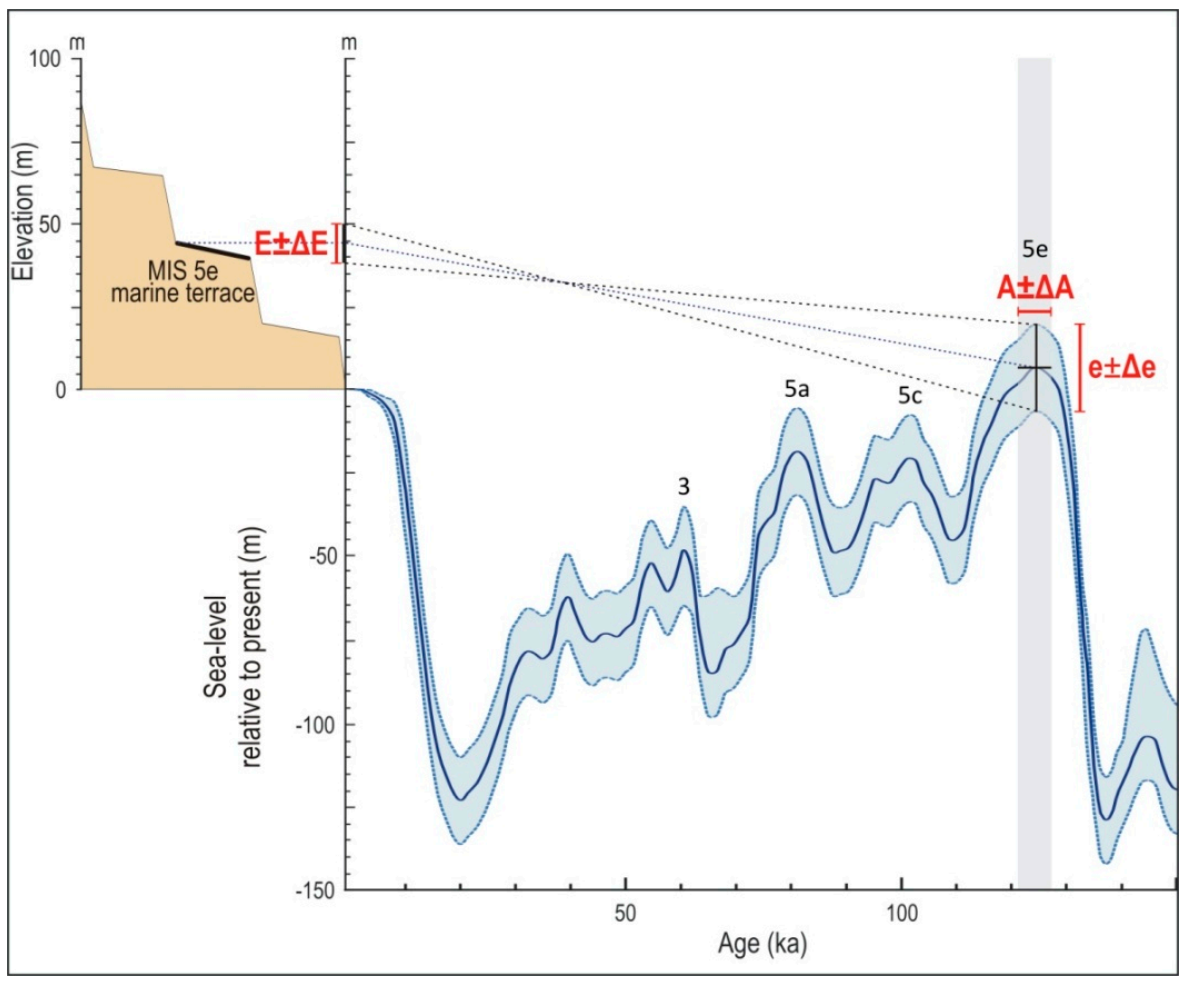

Figure 3. Schematic representation of the uncertainties taken into account for the long-term uplift rates estimations, as well as for the correlation of the marine terraces with past sea-level highstands. $\mathrm{E}$ is the present-day elevation of the inner edge of the terrace, $\mathrm{A}$ is the age of the terrace, e corresponds to the elevation of the sea level at the time of terrace formation, and the delta symbols $(\Delta)$ represent the estimated uncertainty in the different parameters. The marine terrace of MIS 5e is used as an example. 
Errors regarding the eustatic sea-level curve are mainly associated with uncertainties in the age of the marine terraces (A) since the palaeoshoreline does not represent a specific age but the duration of the sea-level highstands, as well as with the position of the sea level at that time (e) (Figure 3). To estimate the uncertainties due to the age extend of the MIS, we adopted the time boundaries of the MIS highstands from Lisiecki and Raymo [88].

The errors of estimation of the marine terrace inner edges' elevation are associated with uncertainties on the accuracy of both the $2 \mathrm{~m}$ cell size DEM and the DGPS measurements. Another error in elevation measurements is related to the precision of the definition of the inner edges as the shoreline angle of emerged older marine terraces is commonly concealed when the paleo-cliffs and/or paleo-platforms are affected by scarp diffusion, river incision, or aeolian depositional processes, or a combination thereof [16]. For long-term uplift rate estimates, we took into consideration a measurement error of $\pm 1 \mathrm{~m}$ for the elevation of the inner edge associated with the accuracy of the DEM and the DGPS system used, while an additional error range of $\pm 1 \mathrm{~m}$ due to mislocation of the inner edges' elevation was also considered $[16,41]$. Therefore, the accuracy of the determination of the palaeo-shoreline angle elevations is quite good as the total average vertical uncertainty in elevation estimates of shoreline angles due to both the vertical mislocation error of the inner edge and the vertical standard mean square error on the DEM and DGPS used, is $\pm 2 \mathrm{~m}$. It should be noted that this error is negligible in estimating the long-term Quaternary uplift rates involving periods of tens to hundreds of thousands of years [88]. We applied Equations (1), (2) and (3) for the two OSL-dated marine terraces of the study area and a long-term uplift rate has been estimated.

The age of the other undated terraces has been inferred from their correlation with past MIS sea-level highstands. Assuming a temporally constant uplift rate $[4-6,8,20,89]$ and taking into account the duration of each MIS [88] as well as the maximum and minimum position of eustatic sea-level for each MIS highstand [25], we estimated the "expected" (or "predicted") elevation ranges of the inner edge for each MIS marine terrace. The predicted elevations were then compared with the observed elevations of the marine terraces, and for each terrace, an MIS was assigned. This is a model generally used since the dating of marine terraces is sometimes difficult, and very often, only one-if any-terrace can be reliably dated.

\section{Results and Discussion}

\subsection{Mapping}

The application of mapping techniques led to the identification of a sequence of 10 uplifted marine terraces along the coastline between cape Koulendi and Agia Marina, west of cape Maleas, with inner edges' elevation ranging between $8 \pm 2 \mathrm{~m}$ and $172 \pm 2 \mathrm{~m}$ (Figures 4 and 5). On Elafonissos Island, the marine terraces flight, consisting of 10 emerged abrasion platforms, can be traced with shoreline angles (inner edges) ranging in elevation from $8 \pm 2 \mathrm{~m}$ to $192 \pm 2 \mathrm{~m}$. A detailed map of the marine terraces (numbered T1-T10 starting from the youngest and lowermost towards the highest and oldest) is presented in Figure 4.

Marine terraces in the study area are mainly characterized by well preserved wave-cut surfaces carved on marine and lacustrine sediments of the Pleistocene age. Some of them, especially those along the coast between Paleokastro and Sfontili and partially those on the Elafonissos Island, have developed on Mesozoic limestone and dolomites in the form of bedrock terraces, whereas between Neapolis and Paleokastro, they are built on top of the metamorphic rocks of the Mesozoic bedrock. At the area of Neapolis, remnants of dissected marine platforms occur on fluvio-terrestrial deposits of lower Pleistocene age. Between Cape Punda and Neapolis, the lateral morphological continuity of the terraces is interrupted due to the fluvial erosion of the marine-lacustrine Late Pleistocene sedimentary formations caused by the channels of well-developed drainage networks that dissect the palaeo-surfaces. 


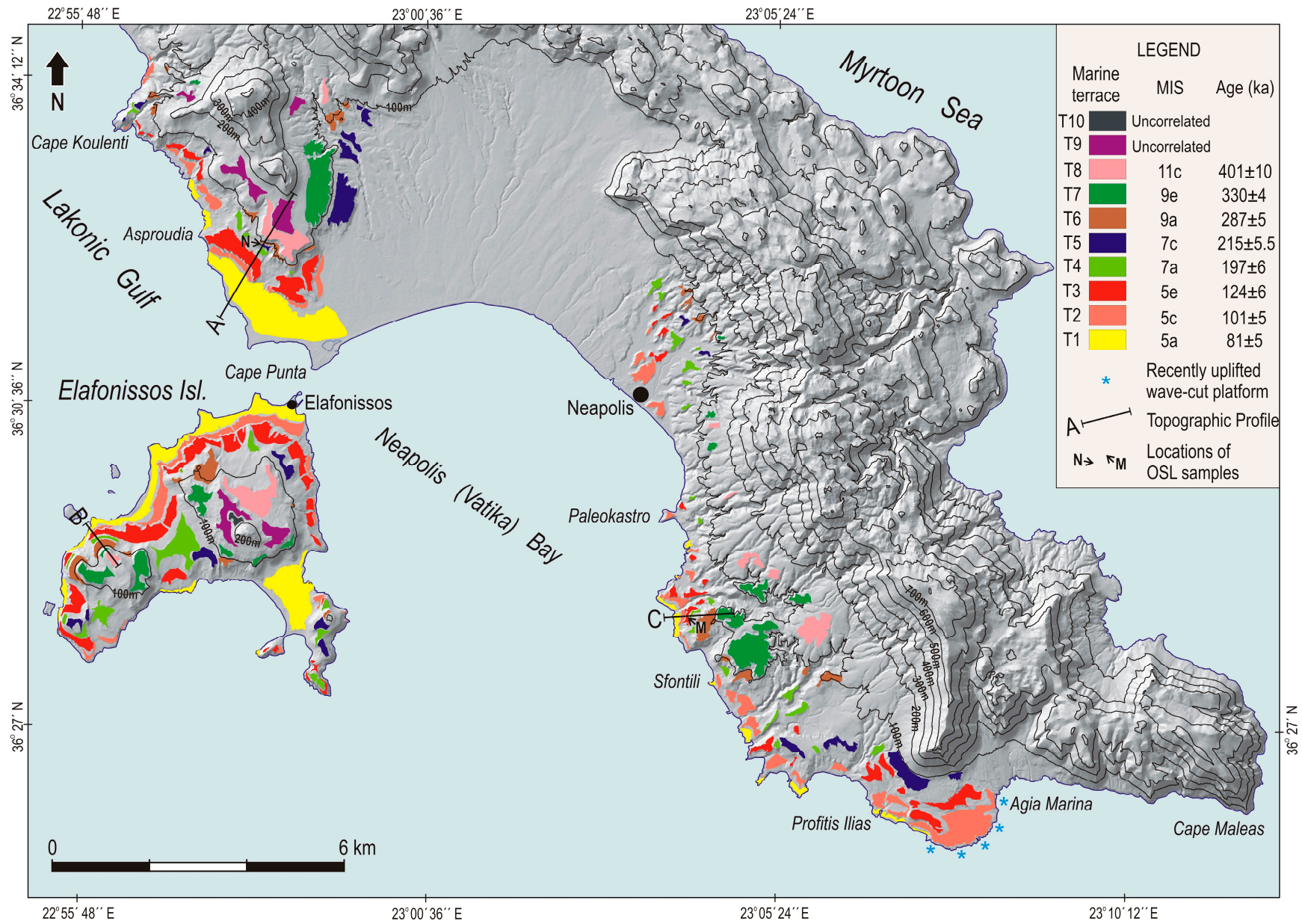

Figure 4. Geographic distribution of the uplifted marine terraces of the broader Neapolis area, southeastern Peloponnese. The location of the topographic profiles, as well as the location of the OSL samples, are also depicted.

The lithology of the geological formations and their relative erodibility seem to play an important role in the extension of the marine terraces' surface. Marine terraces developed on Pliocene-Pleistocene formations as well as on metamorphic rocks are more extensive in relation to those carved into limestone and dolomites. The surfaces of some of the bedrock marine terraces eroded into Mesozoic limestones and dolomites have also been affected by karst processes.

Three topographic profiles were drawn across the terraces and roughly perpendicular to the coastline at three locations of the study area (Figure 6). None of the three profiles contains the entire terrace sequence. The elevation values measured for the shoreline angles of the different terraces along the profiles are illustrated in Figure 6. Topographic Profile A was constructed $2.3 \mathrm{~km}$ northwest of Cape Punta (Figure 5a,b). It is $2.2 \mathrm{~km}$ long and extends from sea level to a maximum elevation of $165 \mathrm{~m}$. It contains seven marine terraces (terrace T7, along with the highest terraces T9 and T10, are not represented in this profile. A sedimentary block sample (N) for OSL dating was collected from the caprock of T5, very close to the inner edge of this terrace (Figures 5e and 6). Profile 2, constructed at the western part of the Elafonissos Island, has a length of $740 \mathrm{~m}$ and reaches a maximum elevation of $160 \mathrm{~m}$ (Figure 6). It revealed a staircase of seven marine terraces (T1, T2, T3, T4, T6, T7, and T8) separated by relatively steep palaeo-cliffs. Samples taken from the sedimentary blocks of the two lower terraces along this profile did not give reliable OSL ages. Topographic Profile 3 was constructed $4.6 \mathrm{~km}$ south of Neapolis. It is $1.21 \mathrm{~km}$ long and extends from the coastline to a maximum elevation of $140 \mathrm{~m}$. This profile cut a sequence of six terraces (T1, T2, T3, T4, T6, and T7). A sedimentary block sample (M) was taken from the caprock 
close to the inner edge of $\mathrm{T} 3$ for OSL dating. The elevation of the inner edges of the terraces remains roughly constant in all three profiles (Figure 6), indicating that there is no evidence for coast-parallel tilting of the marine terraces in the study area.
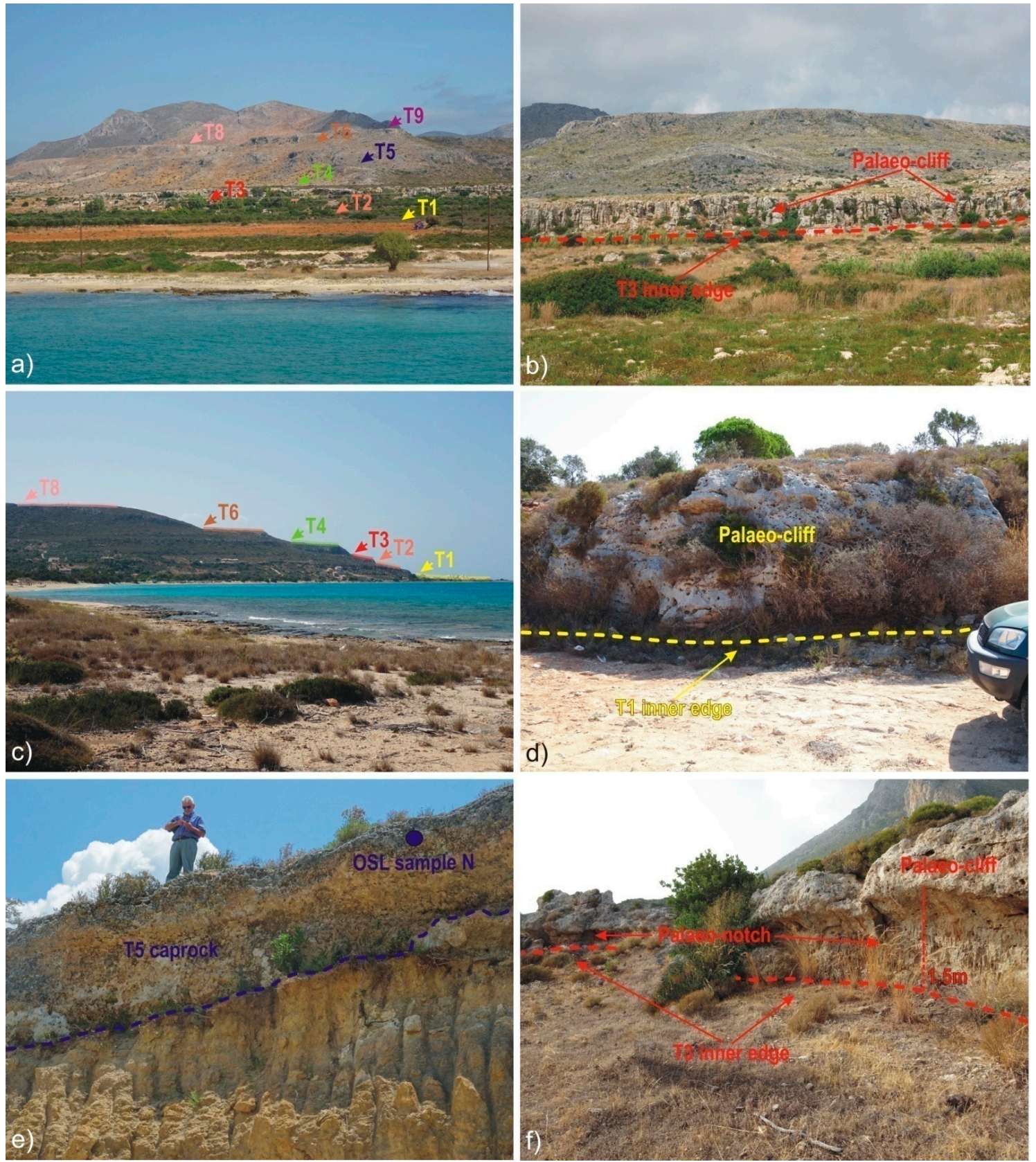

Figure 5. (a) View of the flight of marine terraces northwest of Cape Punta. Colored arrows (same colors as Figure 4) point to terraces T1, T2, T3, T4, T5, T6, T8, and T9 (b) View of the paleo-shoreline angle of terrace T3 (corresponding to MIS 5e sea-level highstand) north of Cape Punta. (c) Profile view of the terrace sequence on the western part of the Elafonissos Island (d) View of the inner edge of terrace T3 (corresponding to MIS 5a sea-level highstand) at the north part of Elafonissos. (e) Outcrop of Terrace T5 caprock, northwest of Cape Punta. The position of the sedimentary block sample N collected for OSL dating is also depicted (f). View of the inner edge of terrace T3 (corresponding to MIS 5e sea-level highstand) northeast of Profitis Ilias. 

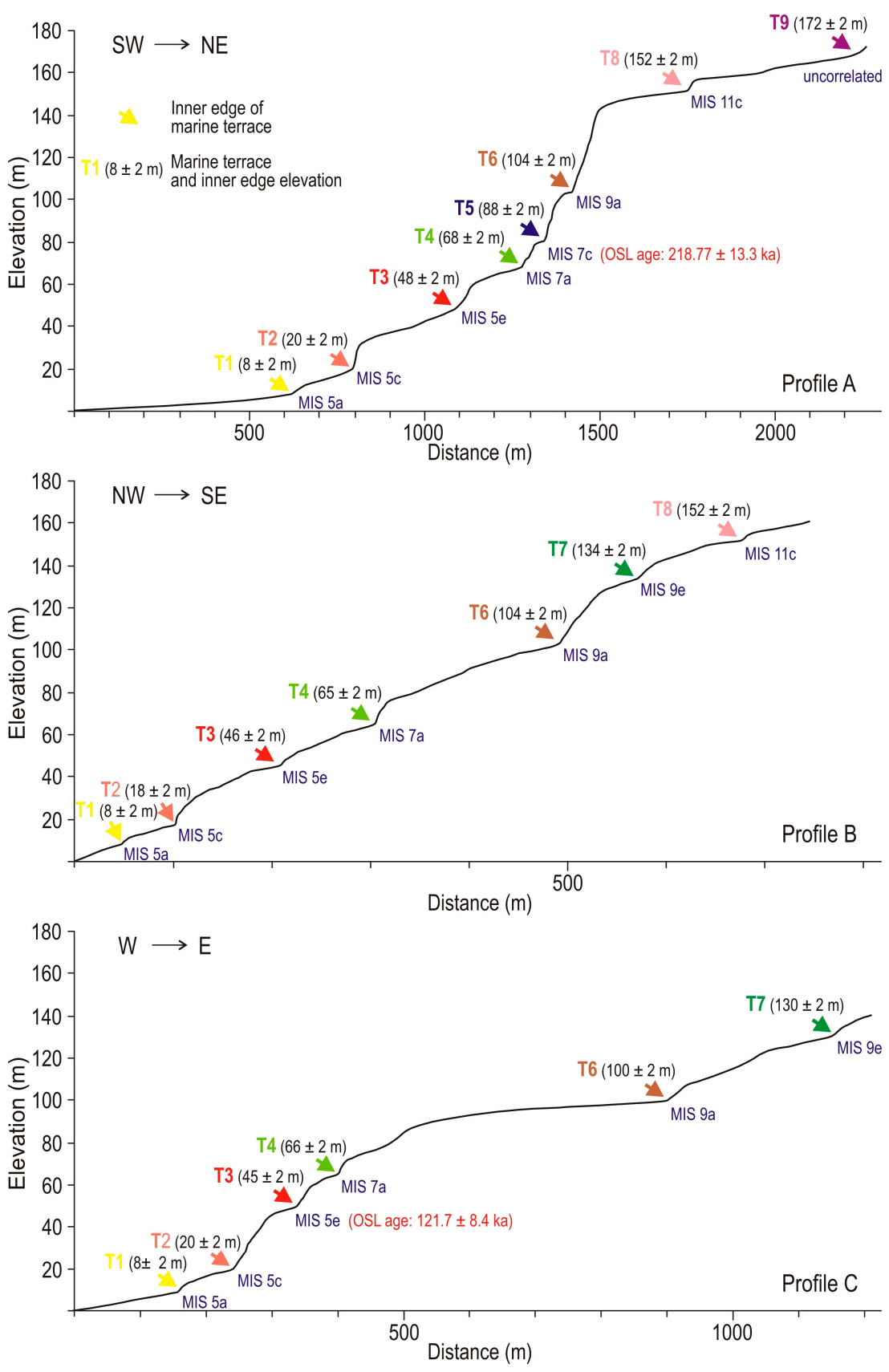

Figure 6. Three topographic profiles constructed $2.3 \mathrm{~km}$ northwest of Cape Punta (Profile A), at the western part of the Elafonissos Island (Profile B), and $4.6 \mathrm{~km}$ south of Neapolis (Profile C). For locations of the profiles, see map in Figure 4. The marine terraces are numbered consecutively, starting with the lowest one. The elevations of the inner edges for the terraces, as derived from the topographic profiles, are provided. The location and the age of the OSL samples, as well as the MIS attributed to each marine terrace, are also given.

\subsection{Optically Stimulated Luminescence (OSL) Ages and Tectonic Uplift}

The results of the application of the OSL dating technique to the samples collected from the caprock outcrops of two of the terraces are depicted in Table 1.

To estimate mean uplift rates, we modeled the elevations of the inner edges of the terraces T3 and T5 with the OSL dates of the sedimentary block samples collected from the caprock of these palaeo-platforms. Our preferred correlation of these two OSL dated marine terraces with the MIS highstands of the sea-level curve proposed by Waelbroeck et al. [25] allowed us to quantify rate ranges of vertical uplift by applying the above-given 
formulas 1, 2, and 3 (Figure 3, Table 2). In the following, this approach is described for the two terraces, $\mathrm{T} 3$ and $\mathrm{T} 5$.

Table 1. Radionuclide concentrations, dose rates, equivalent doses, and OSL ages for collected samples.

\begin{tabular}{|c|c|c|c|c|c|c|c|c|c|}
\hline $\begin{array}{l}\text { Sample } \\
\text { ID }\end{array}$ & $\begin{array}{l}\text { Marine } \\
\text { Terrace }\end{array}$ & $\begin{array}{c}\text { Water } \\
\text { Content }(\%)^{a}\end{array}$ & $\begin{array}{c}{ }^{238} \mathrm{U} \\
(\mathrm{Bq} / \mathrm{kg})^{\mathrm{b}}\end{array}$ & $\begin{array}{c}{ }^{232} \mathrm{Th} \\
(\mathrm{Bq} / \mathrm{kg})^{\mathrm{b}}\end{array}$ & $\begin{array}{c}{ }^{40} \mathrm{~K} \\
(\mathrm{~Bq} / \mathrm{kg})^{b}\end{array}$ & $\begin{array}{c}\text { Total Dose } \\
\text { Rate }(\mathrm{Gy} / \mathrm{ka})^{\mathrm{c}}\end{array}$ & $n^{d}$ & $\begin{array}{c}\text { Equivalent } \\
\text { Dose De (Gy) }\end{array}$ & $\begin{array}{l}\text { Age } \\
(\mathbf{k a})^{f}\end{array}$ \\
\hline $\mathrm{M}$ & T3 & $5.0 \pm 10$ & $12.5 \pm 0.3$ & $11.4 \pm 0.4$ & $127.5 \pm 2.2$ & $1.02 \pm 0.04$ & $16(24)$ & $124.5 \pm 7.9$ & $121.7 \pm 8.4$ \\
\hline $\mathrm{N}$ & T5 & $5.0 \pm 10$ & $17.3 \pm 0.4$ & $6.1 \pm 0.3$ & $69.6 \pm 2.2$ & $0.82 \pm 0.03$ & $23(24)$ & $179.4 \pm 9.3$ & $218.8 \pm 13.3$ \\
\hline
\end{tabular}

${ }^{a}$ Water content expressed as a percentage of the mass of dry sediment, calculated using field values. ${ }^{b}$ Concentrations of ${ }^{238} \mathrm{U},{ }^{232} \mathrm{Th}$, and ${ }^{40} \mathrm{~K}$ were determined from laboratory measurements using high-resolution gamma spectrometry. ${ }^{c}$ Beta, gamma, and cosmic dose rates were combined to calculate the total dose rates after Aitken [90]. Beta and gamma dose rates were calculated using the conversion factors of Liritzis et al. [79]. Beta dose rates have been corrected for the effect of the water content, grain size, and chemical etching. Gamma dose rates have been corrected for the effect of the water content. Cosmic dose rates were calculated according to Prescott and Hutton (1994) [91]. ${ }^{d}$ The number of aliquots accepted/measured. ${ }^{e}$ Equivalent dose values were determined using the central age model (CAM) of Galbraith et al. [92]. ${ }^{\mathrm{f}}$ Ages before 2016 AD.

Table 2. Calculation of uplift rates of the inner edges of terraces T3 and T5 along Profiles 1 and 3 at the locations where the samples for OSL dating were collected. For the calculations of the errors associated with the position of the sea-level at the time of the formation of the terraces, we used the sea-level curve of Waelbroeck et al. [25], while for the uncertainties due to the duration of the MIS, we adopted the time boundaries of the MIS highstands from Lisiecki and Raymo [88].

\begin{tabular}{|c|c|c|c|c|c|c|c|c|c|c|}
\hline \multirow[t]{2}{*}{$\begin{array}{c}\text { Sample } \\
\text { ID }\end{array}$} & \multirow[t]{2}{*}{ OSL Age (ka) } & \multirow[t]{2}{*}{$\begin{array}{l}\text { Marine } \\
\text { Terrace }\end{array}$} & \multirow{2}{*}{$\begin{array}{c}\begin{array}{c}\text { Inner Edge } \\
\text { Elevation (m) }\end{array} \\
\qquad \begin{array}{c}\mathrm{E} \pm \Delta \mathrm{E}\end{array}\end{array}$} & \multirow[t]{2}{*}{$\begin{array}{l}\text { Assigned } \\
\text { MIS }\end{array}$} & \multirow{2}{*}{$\begin{array}{c}\text { Assigned } \\
\text { MIS Age (ka) } \\
\begin{array}{c}\mathrm{A} \pm \Delta \mathrm{A}\end{array}\end{array}$} & \multicolumn{2}{|c|}{ Eustatic Estimations (m) } & \multicolumn{3}{|c|}{ Uplift Rate (mm a $\left.{ }^{-1}\right)$} \\
\hline & & & & & & $\begin{array}{l}\text { Max. Elevation of } \\
\text { the Sea-Level at } \\
\text { the Time of the } \\
\text { Assigned MIS }\end{array}$ & $\begin{array}{c}\text { Min. Elevation of } \\
\text { the Sea-Level at } \\
\text { the Time of the } \\
\text { Assigned MIS }\end{array}$ & Umax & Umin & $\mathbf{U}$ \\
\hline M & $121.71 \pm 8.42$ & T3 & $50 \pm 2$ & $5 e$ & $124 \pm 6$ & +19 & -7 & 0.50 & 0.23 & $0.37 \pm 0.13$ \\
\hline $\mathrm{N}$ & $218.77 \pm 13.3$ & T5 & $80 \pm 2$ & $7 \mathrm{c}$ & $215 \pm 5.5$ & -17 & +9 & 0.47 & 0.31 & $0.39 \pm 0.08$ \\
\hline
\end{tabular}

The OSL age of the sample M collected from the T3 outcrop (topographic profile 3) ranges between 130.1 and $113.3 \mathrm{ka}$, strongly suggesting that $\mathrm{T} 3$ was formed during the prominent sea-level highstand corresponding to MIS 5e at $124 \pm 6$ ka ago (Table 2, Figure 7). Terrace T3 is relatively well preserved, and its formation during MIS 5e is supported by the observation that marine terraces formed during that stage are generally well preserved in the geomorphologic record of many tectonically active regions $[4,5,12,93,94]$. According to Lisiecki and Raymo [88], MIS 5e began possibly $130 \mathrm{ka}$ ago, and the high sea level was sustained until $118 \mathrm{ka}$ ago and then fell rapidly. Taking into consideration the eustatic sea-level curve of Waelbroeck et al. [25], during this highstand, sea-level reached $+6 \mathrm{~m}$ above present m.s.l. (with a minimum of $-7 \mathrm{~m}$ below present-day m.s.l. and a maximum of $+19 \mathrm{~m}$ above present-day m.s.l.). As the elevations of the inner edge of this terrace at the sampling site are located at $50 \pm 2 \mathrm{~m}$ above m.s.l. (Profile 3 in Figure 6), the maximum and minimum corrected elevations, taking into account the maximum and minimum eustatic sea-level at its formation time, are 30 and $59 \mathrm{~m}$ above m.s.l., respectively. Hence, the resulting maximum and minimum uplift rates would be 0.50 and $0.23 \mathrm{~mm} \mathrm{a}^{-1}$, respectively, which means a mean long-term uplift rate of $0.37 \pm 0.13 \mathrm{~mm} \mathrm{a}^{-1}$ over the last $124 \pm 6 \mathrm{ka}$ (Table 2).

The sedimentary block sample N, collected from a caprock outcrop of marine terrace T5, $2.3 \mathrm{~km}$ northwest of Cape Punta (Profile 1 in Figure 6), gave an OSL age of $218.77 \pm 13.3 \mathrm{Ka}$. This date indicates that T6 formed during the prominent sea-level highstand of MIS 7c (Table 2, Figure 7). This sea-level highstand began $220.5 \mathrm{ka}$ ago and lasted till about $209.5 \mathrm{ka}$ ago [88]. The elevation of the inner edge of T5 at the location where the OSL sample was collected is $80 \pm 2 \mathrm{~m}$ above m.s.l. (Profile 1 in Figure 6), and sea-level during the correlative isotope stage $7 \mathrm{c}$ was $-4 \mathrm{~m}$ lower than at present (with a minimum of $-17 \mathrm{~m}$ below and a 
maximum of $+9 \mathrm{~m}$ above present-day m.s.1.). Taking into consideration the uncertainties regarding the inner edge elevation $( \pm 2 \mathrm{~m})$, the eustatic sea-level at the time of the formation of T5, and the duration of the MIS 7c, maximum and minimum uplift rates of 0.47 and $0.31 \mathrm{~mm} \mathrm{a}^{-1}$, respectively, are estimated. Thus, the long-term mean uplift rate for the last $215 \pm 5.5 \mathrm{ka}$ is $0.39 \pm 0.08 \mathrm{~mm} \mathrm{a}^{-1}$ (Table 2). This value is in good agreement with the long-term uplift rate of $0.37 \pm 0.13 \mathrm{~mm} \mathrm{a}^{-1}$ over the last $124 \pm 6 \mathrm{ka}$ resulting from the correlation of terrace T3 with MIS 5e. It should be noted that to gain more insight on uplift variations through time, different terrace surfaces within the same profiles must be dated and their uplift rates compared.

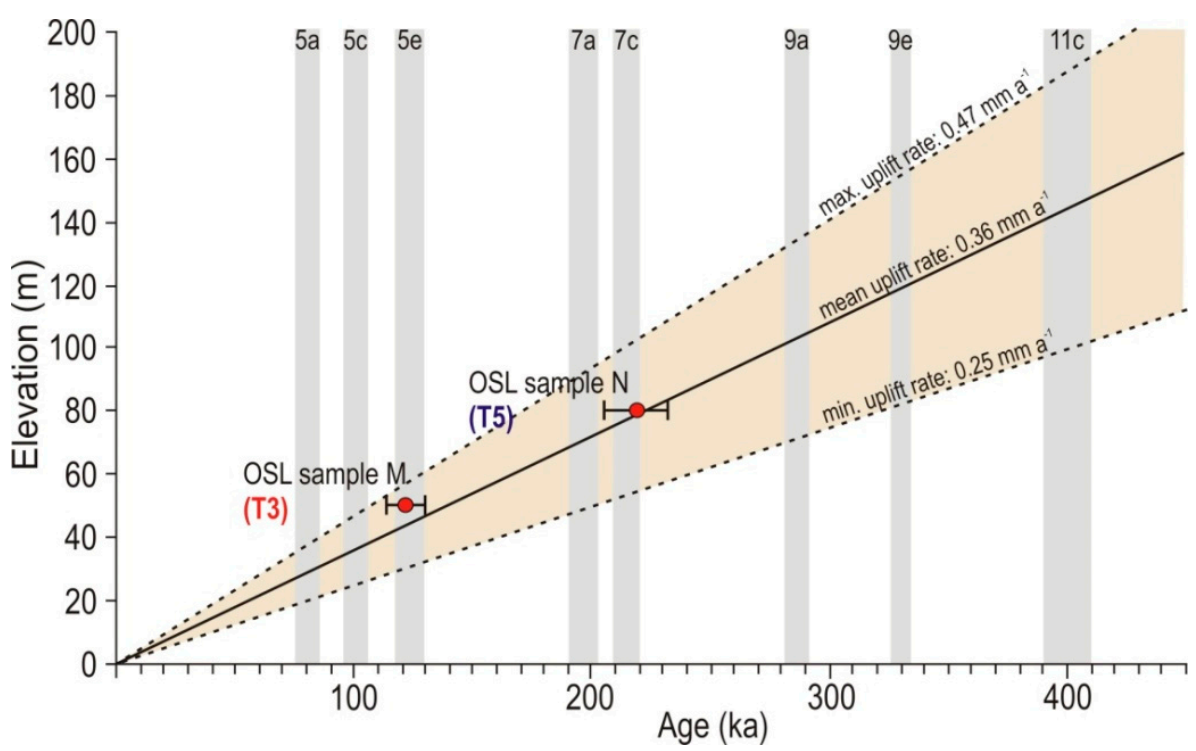

Figure 7. Correlation diagram of the two OSL dated samples, collected from marine terraces T3 and T5, respectively, with late Quaternary MIS. Gray vertical bands correspond to the age extent of the different sea-level highstands (from Lisiecki and Raymo [88]). Mean, maximum, and minimum uplift rates from this correlation are also shown.

Along the coastline of the southeastern part of the study area, between Profitis Ilias and Agia Marina, uplifted abrasion platforms up to $2 \pm 0.5 \mathrm{~m}$ above present-day m.s.l. are observed (Figures 4 and 8). In some cases, these uplifted surfaces are backed by a low, steep cliff with a tidal notch at its base, indicating the position of the recent palaeo-shoreline (Figure $8 a, b)$. Although we did not date these recently raised sea-level indicators, it is evident by their presence that the prevailing late Pleistocene tectonic movement remained positive (uplift) during the Holocene.

Mean long-term uplift rates estimated in this study are higher than the mean uplift rates estimated for the study area by Kourampas [54], who focused on the study of the late Pleistocene sedimentary facies at the broader region of the Lakonic Peninsula. He suggested a long-term uplift rate ranging from 0.08 to $0.33 \mathrm{~mm} \mathrm{a}^{-1}$ during the last $1 \mathrm{Ma}$. It should be noted that the results of our work are in accordance with regional upper Quaternary uplift rates proposed for Crete Island, a tectonically active region very close to the Hellenic Subduction Zone (Figure 1a). Along the coast of the western part of Crete, as well as along the western-central coasts of the southern part of the island, Pleistocene rock uplift rates range between 0.5 and $1.1 \mathrm{~mm} \mathrm{a}^{-1}$, whereas for the eastern coast of the southern part of the island a mean uplift rate $<0.5 \mathrm{~mm} \mathrm{a}^{-1}$ is suggested $[8,10,20]$. In this area, the role of the local active faults is quite important and differentiates the observed uplift rates from place to place. 

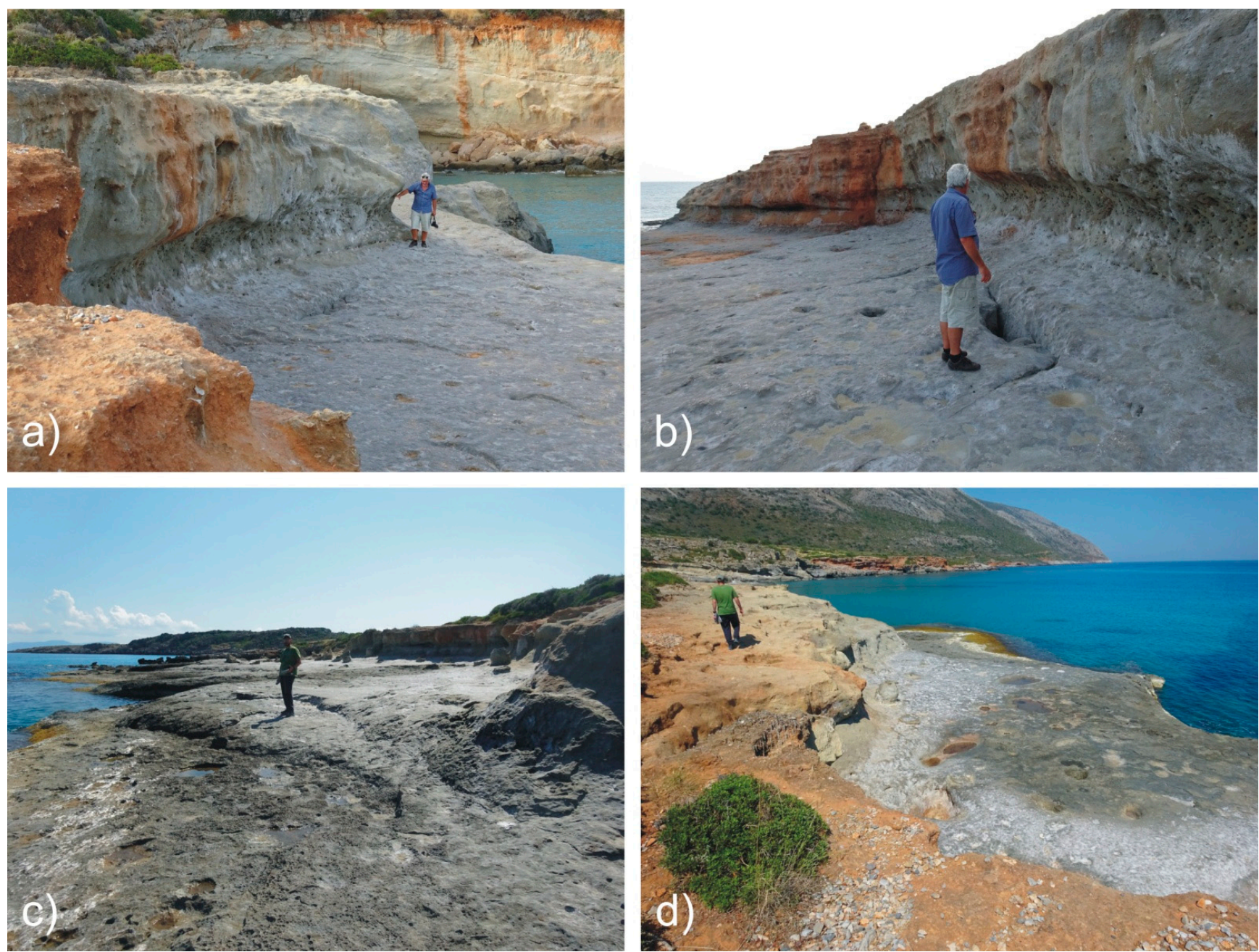

Figure 8. (a,b) Uplifted abrasion platforms between Profitis Ilias and Agia Marina, backed by a low, steep cliff with a tidal notch at its base. (c,d) Uplifted abrasion platforms at Agia Marina.

\subsection{Correlation of the Undated Marine Terraces with Past Sea-Level Highstands}

To assign an age to the undated marine terraces, we have tried to correlate them with past sea-level highstands observed in the eustatic curve [25] using a mean uplift rate of $0.36 \pm 0.11 \mathrm{~mm} \mathrm{a}^{-1}$, estimated from the dated terraces T3 and T5, based on the assumption that this long-term rate remains temporally constant during the late Pleistocene. This approach is consistent with many similar previous studies that linked marine terraces to past sea-level highstands in tectonically active regions $[6,10,14,20,95,96]$. Assuming a constant uplift rate, we estimated the predicted (or expected) elevation ranges of the inner edges for each MIS marine terrace (Table 3). This approach is justified by the fact that the ages of the two OSL dated samples gave similar uplift rates over the last $\sim 125$ and $\sim 220 \mathrm{ka}$. The predicted elevations were compared with the observed real inner edge elevations of the marine terraces of the study area, and for each terrace, an MIS was assigned (Table 3, Figures 9 and 10).

The lowest and thus youngest marine terrace T1, shows good overall morphological continuity, particularly along the north and west shores of Elafonissos Island, as well as along the opposite coast between Cape Pounta and Asproudia (Figure 4). The widest surfaces of this terrace are developed on marine Pleistocene deposits north and northwest of Cape Punta, and at the southeastern part of the Elafonissos Island, T1 is bordered by an inner edge with an elevation of $8 \pm 2 \mathrm{~m}$ above m.s.l. By applying the above estimated average long-term uplift rate of $0.36 \pm 0.11 \mathrm{~mm} \mathrm{a}^{-1}$ to MIS $5 \mathrm{a}$, the younger MIS 5 highstand at $81 \pm 5 \mathrm{ka}$, and taking into consideration that this highstand was lower than the present 
mean sea-level by about $-19 \pm 13 \mathrm{~m}$ [25], a predicted elevation of $12 \pm 4 \mathrm{~m}$ is obtained for the inner edge. The observed present-day elevation of the T1 inner edge $(8 \pm 2 \mathrm{~m}$ above m.s.l.) falls within the predicted elevation range of the MIS 5a marine terrace palaeoshoreline angle (Table 3, Figure 9). Hence we can assign an MIS 5a age to this terrace (Figure 10). This terrace probably corresponds to the surface carved into the PliocenePleistocene formations, recognized at the broader area of Neapolis, Profitis Ilias, and Agia Marina by previous researchers $[51,52,97]$ at elevations ranging from 4 to $7 \mathrm{~m}$ above m.s.l. It was correlated by them with the "Neo-Tyrrhenian" sea-level cycle, which corresponds to MIS 5a; ca. $80 \mathrm{ka}[54,98]$, which is in agreement with our proposal.

Table 3. Name, assigned MIS, age, and observed present-day elevations of the inner edges of the marine terraces in three different locations of the study area. The predicted (or expected) elevation ranges of the inner edges (palaeo-shorelines) for each MIS were calculated under the assumption that the long-term uplift rate $\left(0.36 \pm 0.11 \mathrm{~mm} \mathrm{a}^{-1}\right)$ was constant over the last $401 \pm 10 \mathrm{ka}$ and taking into account the duration of each MIS (according to Lisiecki and Raymo [88], as well as the maximum and minimum position of eustatic sea-level for each MIS highstand (according to sea-level curve by Waelbroeck et al. [25].

\begin{tabular}{|c|c|c|c|c|c|c|c|c|c|}
\hline \multirow{2}{*}{ Terrace } & \multicolumn{3}{|c|}{ Palaeoshoreline (Inner Edge) Elevation in Different Locations (m) } & \multirow{2}{*}{ MIS } & \multirow{2}{*}{$\begin{array}{l}\text { MIS Age } \\
\text { (ka) }\end{array}$} & \multicolumn{3}{|c|}{ Sea-Level Correction (m) } & \multirow{2}{*}{$\begin{array}{l}\text { Predicted Inner } \\
\text { Edge Elevation } \\
(\mathrm{m})\end{array}$} \\
\hline & Elafonissos Island & Punta & Nepolis, Profitis Ilias, Agia Marina & & & min. & mean & max. & \\
\hline T1 & $8 \pm 2$ & $8 \pm 2$ & $8 \pm 2$ & $5 a$ & $81 \pm 5$ & $(-32)$ & $(-19)$ & $(-6)$ & $12 \pm 4$ \\
\hline $\mathrm{T} 2$ & $16-24 \pm 2$ & $20-24 \pm 2$ & $20-24 \pm 2$ & $5 c$ & $101 \pm 5$ & $(-34)$ & $(-21)$ & $(-8)$ & $15 \pm 4$ \\
\hline T3 & $40-48 \pm 2$ & $40-48 \pm 2$ & $40-50 \pm 2$ & $5 e$ & $124 \pm 6$ & $(-7)$ & $(+6)$ & $(+19)$ & $50 \pm 2$ \\
\hline $\mathrm{T} 4$ & $64-68 \pm 2$ & $64-68 \pm 2$ & $64-68 \pm 2$ & $7 a$ & $197 \pm 6$ & $(-23)$ & $(-10)$ & $(+3)$ & $61 \pm 6$ \\
\hline T5 & $80-88 \pm 2$ & $88 \pm 2$ & $84-88 \pm 2$ & $7 \mathrm{c}$ & $215 \pm 5.5$ & $(-17)$ & $(-4)$ & $(+9)$ & $73 \pm 8$ \\
\hline T6 & $104 \pm 2$ & $104-108 \pm 2$ & $100-104 \pm 2$ & $9 a$ & $287 \pm 5$ & $(-29)$ & $(-16)$ & $(-3)$ & $87 \pm 17$ \\
\hline T7 & $128-136 \pm 2$ & $128-136 \pm 2$ & $128-140 \pm 2$ & $9 \mathrm{e}$ & $330 \pm 4$ & $(+18)$ & $(+5)$ & $(-8)$ & $124 \pm 21$ \\
\hline $\mathrm{T} 8$ & $152 \pm 2$ & $152 \pm 2$ & $152-156 \pm 2$ & $11 \mathrm{c}$ & $401 \pm 10$ & $(-7)$ & $(+6)$ & $(+19)$ & $150 \pm 27$ \\
\hline T9 & $172 \pm 2$ & $172 \pm 2$ & - & Uncorrelated & - & - & & & - \\
\hline T10 & $192 \pm 2$ & - & - & Uncorrelated & - & - & & & - \\
\hline
\end{tabular}

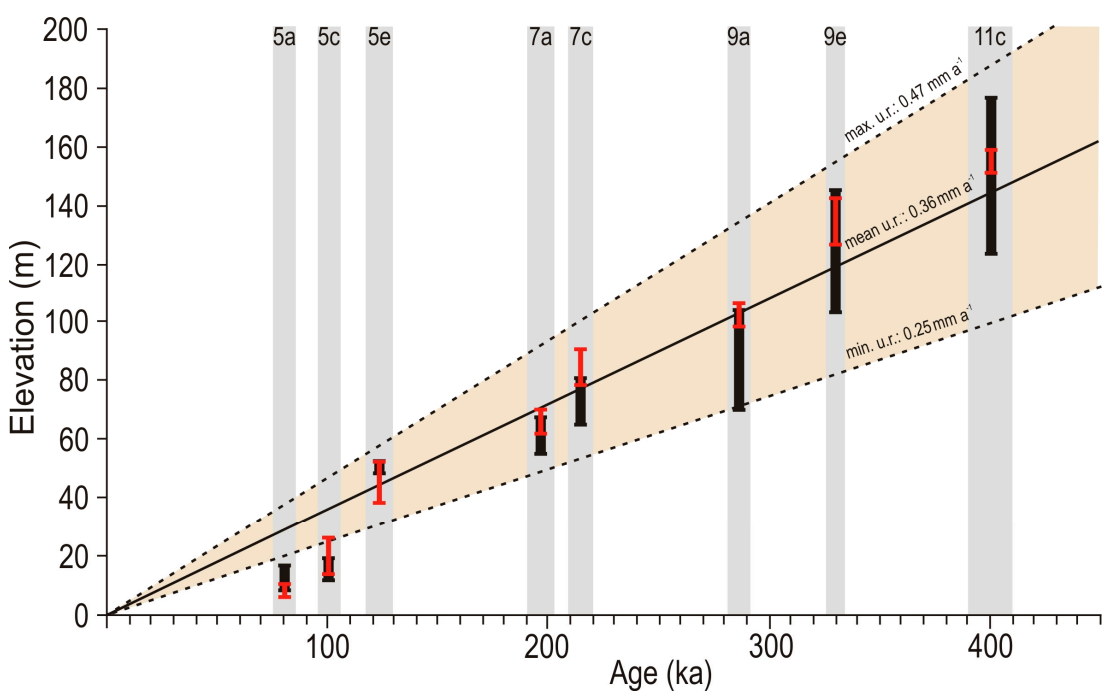

Figure 9. Comparative diagram of the predicted/expected marine terraces' inner edge elevations' ranges (marked by thick black lines) and the observed inner edge elevation ranges (marked by thin red lines) for the broader Neapolis area. The predicted elevation ranges of the inner edges (palaeo-shorelines) for each MIS were calculated under the assumption that the long-term uplift rate $\left(0.36 \pm 0.11 \mathrm{~mm} \mathrm{a}^{-1}\right)$ was constant for the last $401 \pm 10 \mathrm{ka}$ and taking into account the age extend of each MIS highstand (according to Lisiecki and Raymo [88] — marked here as gray vertical bands), as well as the maximum and minimum position of eustatic sea-level for each MIS highstand (according to sea-level curve by Waelbroeck et al. [25]). 


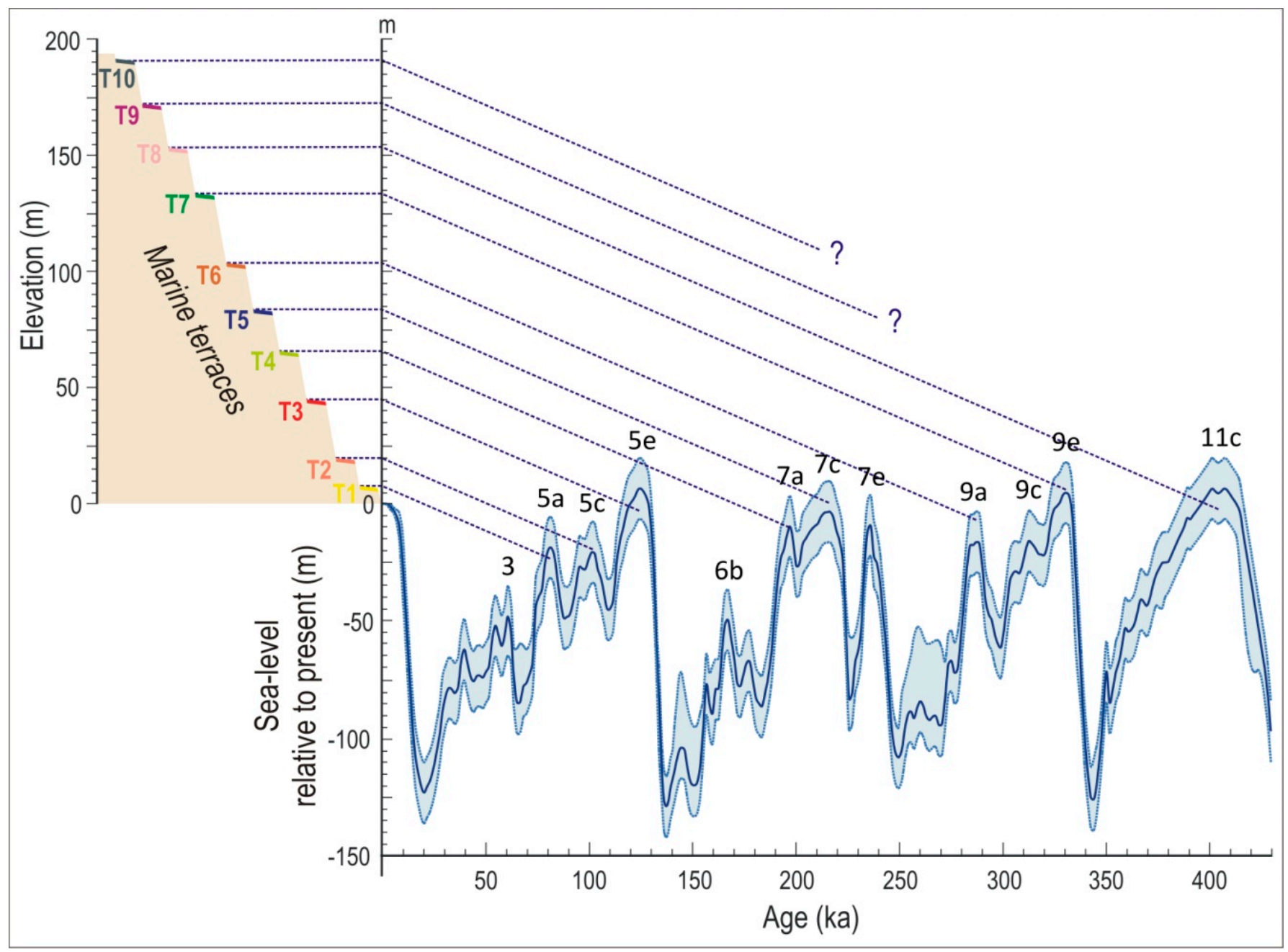

Figure 10. Correlation scheme for the marine terraces on southeastern Peloponnese with late Quaternary MIS sea-level highstands. The sea-level curve (with confidence interval) used is from Waelbroeck et al. [25].

The next higher marine terrace, T2, is relatively well preserved and shows good morphological continuity, following the present coastline. The widest surface of this terrace is carved into marine Pleistocene deposits between Profitis Ilias and Agia Marina, west of Cape Maleas (Figure 4). The current elevation of the shoreline angle of T2 varies between $16 \pm 2$ and $24 \pm 2 \mathrm{~m}$ above m.s.l. For this terrace, there are no dates. However, an age corresponding to MIS $5 \mathrm{c}$ of $101 \pm 5 \mathrm{ka}$ was adopted as the most appropriate. By using the mean uplift rate estimated by the dated terraces and considering that during the MIS $5 \mathrm{c}$ sea-level was located at $-21 \mathrm{~m}$ (with a minimum of $-34 \mathrm{~m}$ and a maximum of $-8 \mathrm{~m}$ below present m.s.l. [25]), the elevation of the inner edge of the terrace formed during MIS 5c should be at $15 \pm 4 \mathrm{~m}$ above m.s.l. which is in agreement with the lower limit of the observed inner edge elevation of T2 (Figure 9). This terrace is possibly the surface reported by Kelletat et al. [52] at elevations ranging between 8 and $20 \mathrm{~m}$. They assigned an "Eu-Tyrrhenian" age (which corresponds to MIS 5e; ca $124 \pm 6 \mathrm{ka}$ ) to this surface. However, we propose the age of MIS $5 \mathrm{c}(101 \pm 5 \mathrm{ka})$ as appropriate for T2 as we correlated the higher terrace T3 with MIS 5e sea-level highstand based on the OSL date of sample M1.

Terrace T4 is a discontinuous surface that was not identified at the broader area of Profitis Ilias-Agia Marina during the field survey (Figure 4). The absence of T4 palaeo-surfaces from this area can be attributed to its destruction by wave activity during subsequent sea-level highstands, when the landward retreat of sea-cliffs formed younger and lower terraces, or to the morphology of the area at the time of its formation. Where present, the 
elevation of the inner edges of T4, is observed between $64 \pm 2$ and $68 \pm 2 \mathrm{~m}$ above m.s.l. and remains roughly constant along the entire coast of the study area. T4 most likely correlates with the MIS 7a sea-level highstand at $197 \pm 6 \mathrm{ka}$. Assuming the $0.36 \pm 0.11 \mathrm{~mm} \mathrm{a}^{-1}$ long-term uplift rate value as constant and that during MIS 7a sea-level was lower than the present m.s.l. by about $-10 \pm 13 \mathrm{~m}$ [25], an elevation of $61 \pm 6 \mathrm{~m}$ is expected for the marine terrace of this highstand (Table 3, Figure 9) which fits well with the observed elevations of T7 inner edges.

Marine terrace T6 is generally a discontinuous surface, not recorded at the southeastern part of the study area (Profitis Ilias-Agia Marina) (Figure 4). This terrace was presumably destroyed in this area due to surface erosional processes after the time of its formation. Along the western coast of Elafonissos Island and northwest of Cape Punta (Profiles 2 and 3 of Figure 6), T6 has the shape of a narrow, relatively morphologically continued bedrock marine terrace eroded into Mesozoic limestones and dolomites. T6 surfaces are bordered by inner edges extending at elevations between $100 \pm 2$ and $108 \pm 2 \mathrm{~m}$ above m.s.l. For this terrace, we assign an age of $287 \pm 5 \mathrm{ka}$, which corresponds to the previous prominent highstand MIS 9a (Figure 10). Considering the long-term tectonic uplift rate of the area and that this highstand was about $16 \pm 13$ m below present m.s.l., this implies that the inner edges of the terrace that corresponds to MIS 9a should be located at elevations of about $87 \pm 17 \mathrm{~m}$, which is not far from the elevations of the inner edges measured for this terrace (Figure 9). The small difference in elevation among the predicted and the measured inner edge elevation may be due to a possible slight change in the uplift rate or due to the long period of erosion of the inner edges of the terrace.

Marine terrace T7 is represented by remnants of extensive, gently seaward-dipping surfaces carved mainly into Mesozoic bedrock (limestones, dolomites, and metamorphic rocks) at the eastern part of the study area and partly into limestones and dolomites on Elafonissos Island. In the area north of Cape Punta, these platforms are exclusively developed on Pleistocene marine sedimentary formations (Figures 2 and 4). T7 palaeoplatform is bounded landwards by inner edges of elevations ranging from $128 \pm 2$ to $140 \pm 2 \mathrm{~m}$ above m.s.l. An age of $330 \pm 4 \mathrm{ka}$, which corresponds to the MIS 9e, is suggested for this terrace (Figure 10). Assuming that the study area has been uplifted with a constant mean rate of $0.36 \pm 0.11 \mathrm{~mm} \mathrm{a}^{-1}$, and considering that sea level during this period was $+5 \mathrm{~m}$ above the present-day m.s.l. (with a minimum of $-8 \mathrm{~m}$ below and a maximum of $+14 \mathrm{~m}$ above m.s.1.) [25], the elevation of the inner edge of the terrace of this highstand should be between $103 \mathrm{~m}$ and $145 \mathrm{~m}$ (Table 3, Figure 9). This predicted elevation coincides with the measured inner edge elevations of T7.

Marine terrace T8 is characterized by extensive, relatively plain surfaces developed on marine Pleistocene deposits, as well as on carbonate and metamorphic rocks of the Mesozoic bedrock (Figures 2 and 4). T8 was not identified in the eastern part of the study area. The palaeoshoreline angle of this terrace is well defined and has been recognized at elevations between $152 \pm 2$ and $156 \pm 2 \mathrm{~m}$ above m.s.l. The MIS 11c at $407 \pm 10 \mathrm{ka}$ was adopted for T8 by applying the previous reasoning (Figure 10). Considering the constant mean long-term tectonic uplift rate proposed by Waelbroeck et al. [25] sea-level position at the interglacial period of MIS 11c (+6 m above m.s.l-- between $-6 \mathrm{~m}$ below and $+19 \mathrm{~m}$ above m.s.1.), a correlation with MIS 11c seems reasonable. The inner edge of the marine terraces of this highstand should be at $150 \pm 27 \mathrm{~m}$, which is similar to the observed inner edge elevation of T8 (Table 3, Figure 9).

T9, the second-highest marine terrace, exists in Elafonissos Island and at the opposite coast between Cape Punta and Cape Koulenti (Figure 4). It is developed exclusively on the Mesozoic bedrock, and its inner edges were recorded at $172 \pm 2 \mathrm{~m}$ above m.s.l. On top of Elafonissos Island, the highest and oldest surface (T10) occurs with the inner edge at about $192 \pm 2 \mathrm{~m}$ above m.s.l. (Figure 4). T10 is not present on the opposite continental coasts of the study area. The morphological discontinuity of these 2 highest terraces (T9 and T10), in addition to their heavily eroded inner edges and the lack of highly reliable global sea-level 
curves before $450 \mathrm{ka}$, made precise mapping and correlation difficult (Figure 10). Probably they were formed during the MIS sea-level highstands before $407 \pm 10 \mathrm{ka}$.

As already mentioned, previous studies [52,54] have reported a sudden southward inclination and submergence of the older marine palaeo-platforms, whereas the terraces are supposedly higher on Elafonisos Island than on the opposite Punta-Neapolis area. The results of our approach are not in agreement with this trend. The fact that the two successfully OSL dated marine terraces had different ages and were collected from different locations of the study area, but gave similar rates of long-term tectonic uplift, suggests that the area is being emerged uniformly in both space and time, at least for the past $\sim 400 \mathrm{ka}$. Another strong evidence for the almost uniform tectonic uplift of the region is that according to the results of the analysis of the detailed DEM and their validation, where possible, in the field, we detected a uniform morphological distribution of the surfaces and inner edges of each marine terrace at similar elevation ranges throughout the study area. The spatially uniform uplift around Neapolis is very different from the well-known examples in Crete and Corinth $[4,6,8-11,20,29,42-50]$, where terrace elevations are heavily influenced by local active faults on and offshore and vary in elevations over distances of a few kilometers. The DEM of the area suggests there is not much active faulting onshore, but the uniform terrace elevations give the suggestion that, on a broader scale, the uplift is rather a subduction signal than an offshore normal fault signal. Hence, the driving factor of the tectonic uplift is associated with the active subduction of the African lithosphere beneath the Eurasian plate since the area is situated very close $(\sim 90 \mathrm{~km})$ to the active margin of the Hellenic subduction zone.

\section{Conclusions}

The application of GIS analysis, DGPS techniques, and conventional field-mapping methods along the coasts of the broader area of Neapolis in southeastern Peloponnese, enabled us to recognize and map a sequence of 10 tectonically uplifted marine terraces with inner edges ranging in elevations from $8 \pm 2$ to $192 \pm 2 \mathrm{~m}$ above m.s.l. The presence of marine deposits of Pliocene-Lower Pleistocene age up to the elevation of $\sim 180 \mathrm{~m}$ above m.s.l., along with the presence of the flight of preserved marine terraces, demonstrate that the area was affected by a vigorous tectonic uplift during the late Quaternary. Additionally, the presence of recently raised wave-cut shore platforms up to $+2.5 \mathrm{~m}$ above m.s.l. indicates that the positive tectonic movement of the area continues during the Holocene.

Two sedimentary block samples collected from 2 of the marine terraces (T3 and T5) have been OSL dated and gave burial ages (with associated standard errors) of $121.7 \pm 8.4$ and $218.8 \pm 13.3$, respectively. These OSL ages yielded constraints for correlating T3 and T5 to the prominent sea-level highstand of MIS 5e (124 $\pm 6 \mathrm{ka})$ and $7 \mathrm{c}(215 \pm 5.5 \mathrm{ka})$ and to estimate a mean long-term tectonic uplift rate of $0.36 \pm 0.11 \mathrm{~mm} \mathrm{a}^{-1}$ over the last $215 \pm 5.5 \mathrm{ka}$. However, to gain more insight on uplift variations through time, more terrace levels must be dated and their uplift rates compared.

The assumption that the long-term uplift rate remained temporally constant during the Pleistocene permitted the correlation of six of the undated terraces of the sequence with the past sea-level highstands observed in the global eustatic curve. The lowermost Terrace, T1, can be correlated to sea-level highstand MIS 5a, whereas T1, T2, T4 T6, T7, and T8 were correlated with MIS 5a, 5c, 7a, 9a, 9e, and 11c sea-level highstands, respectively. We were not able to correlate the two higher marine terraces, which probably were formed before $401 \pm 1$ ka ago.

The results of this study showed that the broader Neapolis area is being emerged uniformly in both space and time, at least for the past $\sim 400 \mathrm{ka}$, while the driver of tectonic uplift is the active subduction of the African lithosphere beneath the Eurasian plate.

Author Contributions: Conceptualization, E.K., K.T. and K.G.-P.; methodology, E.K., K.T., I.T., K.G.-P., D.P., D.-V.B. and K.S.; software, E.K., K.T. and D.-V.B.; validation, E.K., K.T., K.G.-P. and D.P.; formal analysis, K.T., I.T. and K.S.; investigation, E.K., K.T., I.T., K.G.-P., D.P., D.-V.B. and K.S.; data curation, E.K., K.T., I.T., D.-V.B. and K.S.; writing-original draft preparation, E.K. and I.T.; writing-review 
and editing, E.K., K.T., I.T., K.G.-P., D.P., D.-V.B. and K.S.; visualization, E.K. and K.T.; supervision, E.K. All authors have read and agreed to the published version of the manuscript.

Funding: This research received no external funding.

Data Availability Statement: The data presented in this study are available on request from the corresponding author.

Acknowledgments: We would like to thank Gino de Gelder and an anonymous reviewer for their comments and suggestions that significantly improved the final version of the paper.

Conflicts of Interest: The authors declare no conflict of interest.

\section{References}

1. Lajoie, K.R. Coastal tectonics. In Active Tectonics-Geophysics Series; Wallace, R., Ed.; National Academy Press: Washington, DC, USA, 1986; pp. 95-124.

2. Marquardt, C.; Lavenu, A.; Ortlieb, L.; Godoy, E.; Comte, D. Coastal neotectonics in Southern Central Andes: Uplift and deformation of marine terraces in Northern Chile $\left(27^{\circ} \mathrm{S}\right)$. Tectonophysics 2004, 394, 193-219. [CrossRef]

3. Pedoja, K.; Husson, L.; Regard, V.; Cobbold, P.R.; Ostanciaux, E.; Johnson, M.E.; Kershaw, S.; Saillard, M.; Martinod, J.; Furgerot, L.; et al. Relative sea-level fall since the last interglacial stage: Are coasts uplifting worldwide? Earth Sci. Rev. 2011, 108, 1-15. [CrossRef]

4. Strobl, M.; Hetzel, R.; Fassoulas, C.; Kubik, P.W. A long-term uplift rate for eastern Crete and geodynamic implications for the Hellenic subduction zone. J. Geodyn. 2014, 78, 21-31. [CrossRef]

5. Merritts, D.; Bull, W.B. Interpreting Quaternary uplift rates at the Mendocino triple junction, northern California, from uplifted marine terraces. Geology 1989, 17, 1020-1024. [CrossRef]

6. Armijo, R.; Meyer, B.; King, G.; Rigo, A.; Papanastassiou, D. Quaternary evolution of the Corinth Rift and its implications for the Late Cenozoic evolution of the Aegean. Geophys. J. Int. 1996, 126, 11-53. [CrossRef]

7. Tortorici, G.; Bianca, M.; de Guidi, G.; Monaco, C.; Tortorici, L. Fault activity and marine terracing in the Capo Vaticano area (southern Calabria) during the Middle-Late Quaternary. Quat. Int. 2003, 101-102, 269-278. [CrossRef]

8. Gallen, S.F.; Wegmann, K.W.; Bohnenstiehl, D.R.; Pazzaglia, F.J.; Brandon, M.T. Active simultaneous uplift and margin-normal extension in a forearc high, Crete, Greece. Earth Planet. Sci. Lett. 2014, 398, 11-24. [CrossRef]

9. Mouslopoulou, V.; Begg, J.; Nicol, A.; Oncken, O.; Prior, C. Formation of Late Quaternary paleoshorelines in Crete, Eastern Mediterranean. Earth Planet. Sci. Lett. 2015, 431, 294-307. [CrossRef]

10. Ott, R.F.; Gallen, S.F.; Wegmann, K.W.; Biswas, R.H.; Hrman, F.; Willet, S.D. Pleistocene terrace formation, Quaternary rock uplift rates and geodynamics of the Hellenic Sunduction Zone revealed from dating of palaeoshorelines on Crete, Greece. Earth Planet. Sci. Lett. 2019, 525, 115757. [CrossRef]

11. Robertson, J.; Roberts, G.P.; Iezzi, F.; Meschis, M.; Gheorghiu, D.M.; Sahy, D.; Bristow, C.; Sgambato, C. Distributed normal faulting in the tip zone of the South Alkyonides Fault System, Gulf of Corinth, constrained using ${ }^{36} \mathrm{Cl}$ exposure dating of late-Quaternary wave cut platforms. J. Struct. Geogr. 2020, 136, 104063. [CrossRef]

12. Cerrone, C.; Ascione, A.; Robustelli, G.; Tuccimei, P.; Soligo, M.; Balassone, G.; Mormone, A. Late Quaternary uplift and sea-level fluctuations along the Tyrrhenian margin of Basilicata-Northern Calabria (southern Italy): New constrains from raised paleoshorelines. Geomorphology 2021, 395, 107978. [CrossRef]

13. Burbank, D.W.; Anderson, R.S. Tectonic Geomorphology, 2nd ed.; Wiley-Blackwell: Chelsea, UK, $2011 ;$ p. 460.

14. Anderson, R.S.; Densmore, A.; Ellist, M. The generation and degradation of marine terraces. Basin Res. 1999, 11, 7-19. [CrossRef]

15. Scott, A.; Pinter, N. Extraction of Coastal Terraces and Shoreline-Angle Elevations from Digital Terrain Models, Santa Cruz and Anacapa Islands, California. Phys. Geogr. 2003, 24, 271-294. [CrossRef]

16. Jara-Muñoz, J.; Melnick, D.; Strecker, M.R. TerraceM: A MATLAB ${ }^{\circledR}$ tool to analyze marine and lacustrine terraces using highresolution topography. Geosphere 2016, 12, 176-195. [CrossRef]

17. Carobene, L.; Dai Pra, G. Middle and Upper Pleistocene sea-level high-stands along the Tyrrhenian coast of Basilicata (southern Italy). Il Quaternario 1991, 4, 173-202.

18. Westaway, R. Quaternary uplift of southern Italy. J. Geophys. Res. 1993, 98, 21741-21772. [CrossRef]

19. Cinque, A.; De Pippo, T.; Romano, P. Coastal slope terracing and relative sea-level changes: Deductions based on computer simulations. Earth Surf. Process. Landf. 1995, 20, 87-103. [CrossRef]

20. Gaki-Papanastassiou, K.; Karymbalis, E.; Papanastassiou, D.; Maroukian, H. Quaternary marine terraces as indicators of neotectonic activity of the Ierapetra normal fault SE Crete (Greece). Geomorphology 2009, 104, 38-46. [CrossRef]

21. Bianca, M.; Catalano, S.; De Guidi, G.; Gueli, A.M.; Monaco, C.; Ristuccia, G.M.; Stella, G.; Tortorici, G.; Tortorici, L.; Troja, S.O. Luminescence chronology of Pleistocene marine terraces of Capo Vaticano peninsula (Calabria, Southern Italy). Quat. Int. 2011, 232, 114-121. [CrossRef]

22. Shackleton, N.J.; Opdyke, N.D. Oxygen isotope and palaeomagnetic stratigraphy of Equatorial Pacific core V28-238: Oxygen isotope temperature and ice volumes on a 105 year and 106 year time scale. Quat. Res. 1973, 3, 39-55. [CrossRef] 
23. Martinson, D.G.; Pisias, N.G.; Hays, J.D.; Imbrie, J.; Moore, T.C., Jr.; Shakleton, N.J. Age dating and the orbital theory of ice ages: Development of a high-resolution 0 to 300,000 years chronostratigraphy. Quat. Res. 1987, 27, 1-29. [CrossRef]

24. Chappell, J.; Omura, A.; Esat, T.; McCulloch, M.; Pandolfi, J.; Ota, Y.; Pillans, B. Reconciliation of late Quaternary sea levels derived from coral terraces at Huon Peninsula with deep-sea oxygen isotope records. Earth Planet. Sci. Lett. 1996, 141, $227-236$. [CrossRef]

25. Waelbroeck, C.; Labeyrie, L.; Michel, E.; Duplessy, J.C.; McManus, J.F.; Lambeck, K.; Baldon, E.; Labracherie, M. Sea-level and deep water temperature changes derived from benthic foraminifera isotopic records. Quat. Sci Rev. 2002, 21, 295-305. [CrossRef]

26. Caputo, R. Sea-level curves: Perplexities of an end-user in morphotectonic applications. Glob. Planet. Chang. 2007, 57, 417-423. [CrossRef]

27. Zazo, C.; Goy, J.L.; Hilaire-Marcle, C.; Gillot, P.Y.; Soler, V.; Gonzalez, J.A.; Dabrio, C.; Ghaleb, B. Raised marine sequences of Lanzarote and Fuerteventura revisited-A reappraisal of relative sea-level changes and vertical movements in the eastern Canary Islands during the Quaternary. Quat. Sci. Rev. 2002, 21, 2019-2046. [CrossRef]

28. Normand, R.; Simpson, G.; Herman, F.; Biswas, R.H.; Bahroudi, A.; Schneider, B. Dating and morpho-stratigraphy of uplifted marine terraces in the Markan subduction zone (Iran). Earth Surf. Dyn. 2019, 7, 321-344. [CrossRef]

29. De Gelder, G.; Fernández-Blanco, D.; Melnick, D.; Duclaux, G.; Bell, R.E.; Jara-Muñoz, J.; Armijo, R.; Lacassin, R. Lithospheric flexure and rheology determined by climate cycle markers in the Corinth Rift. Sci. Rep. 2019, 9, 4260. [CrossRef] [PubMed]

30. Racano, S.; Jara Muñoz, J.; Cosentino, D.; Melnick, D. Variable quaternary uplift along the southern margin of the central Anatolian plateau inferred from modeling marine terrace sequences. Tectonics 2020, 39, e2019TC005921. [CrossRef]

31. Choi, J.H.; Murray, A.S.; Jain, M.; Cheong, C.S.; Chang, H.W. Luminescence dating of well-sorted marine terrace sediments on the southeastern coast of Korea. Quat. Sci. Rev. 2003, 22, 407-421. [CrossRef]

32. Choi, J.H.; Kim, J.W.; Murray, A.S.; Hong, D.G.; Chang, H.W.; Cheong, C.S. OSL dating of marine terrace sediments on the southeastern coast of Korea with implications for Quaternary tectonics. Quat. Int. 2009, 199, 3-14. [CrossRef]

33. Lal, D. Cosmic ray labeling of erosion surfaces: In situ nuclide production rates and erosion models. Earth Planet. Sci. Lett. 1991, 104, 424-439. [CrossRef]

34. Niedermann, S. Cosmic-ray-produced noble gases in terrestrial rocks: Dating tools for surface processes. Rev. Miner. Geochem. 2002, 47, 731-784. [CrossRef]

35. Perg, L.A.; Anderson, R.S.; Finkel, R.C. Use of ${ }^{10} \mathrm{Be}$ and ${ }^{26} \mathrm{Al}$ inventory to date marine terraces, Santa Cruz, California, USA. Geology 2001, 19, 879-882. [CrossRef]

36. Nishiizumi, K.; Winterer, E.L.; Kohl, C.P.; Klein, J.; Middleton, R.; Lal, D.; Arnold, J.R. Cosmic ray production rates of 10Be and $26 \mathrm{Al}$ in quartz from glacially polished rocks. J. Geophys. Res. 1989, 94, 17907-17915. [CrossRef]

37. Muhs, D.R.; Kennedy, G.L.; Rockwell, T.K. Uranium series ages of marine terrace corals from the Pacific coast of North America and implications for last-interglacial sea-level history. Quat. Res. 1994, 42, 72-87. [CrossRef]

38. Maroukian, H.; Gaki-Papanastassiou, K.; Karymbalis, E.; Vouvalidis, K.; Pavlopoulos, K.; Papanastassiou, D.; Albanakis, K. Morphotectonic control on drainage network evolution in the Perachora peninsula, Greece. Geomorphology 2008, 102, 81-92. [CrossRef]

39. Gaki-Papanastassiou, K.; Maroukian, H.; Kourbanian, V. The morphotectonic evolution of the southern half of Kythera island, Ionian sea, Greece, during the Quaternary. Prace Geogr. 2011, 127, 49-60.

40. Karymbalis, E.; Papanastassiou, D.; Gaki-Papanastassiou, K.; Tsanakas, K.; Maroukian, H. Geomorphological study of Cephalonia Island, Ionian Sea, Western Greece. J. Maps 2013, 9, 121-134. [CrossRef]

41. Karymbalis, E.; Papanastassiou, D.; Gaki-Papanastassiou, K.; Ferentinou, M.; Chalkias, C. Late Quaternary rates of stream incision in Northeast Peloponnese, Greece. Front. Earth Sci. 2016, 10, 455-478. [CrossRef]

42. Fernández-Blanco, D.; De Gelder, G.; Lacassin, R.; Armijo, R. A new crustal formed the modern Corinth Rift. Earth Sci. Rev. 2019, 199, 102919. [CrossRef]

43. Sebrier, M. Tectonique Recente d'une Transversale a l'Arc Egeen: Le Golfe de Corinthe et ses Regions Peripheriques; These 3me cycle; Université Paris-Sud: Paris, France, 1977.

44. Dufaure, J.J.; Zamanis, A. Styles neotectoniques et etagements de nivaux marins sur un segment d'arc insulaire, le Peloponnese. In Proceedings of the Conference Niveaux Marins et Tectonique Quaternaire dans l'Aire Mediterraneenne, Paris, France, 29 November 1980; C.N.R.S. Université de Paris II: Paris, France, 1980; pp. 77-107.

45. Keraudren, B.; Sorel, D. The terraces of Corinth (Greece): A detailed record of eustatic sea-level variations during the last 500,000 years. Mar. Geol. 1987, 77, 99-107. [CrossRef]

46. De Martini, M.P.; Pantosti, D.; Palyvos, N.; Lemeille, F.; Mc Neill, L.; Collier, R. Slip rates of the Aigion and Eliki faults from uplifted marine terraces, Corinth Gulf, Greece. Comptes Rendus Geosci. 2004, 336, 325-334. [CrossRef]

47. McNeill, L.C.; Collier, R.E.L. Uplift and slip rates of the eastern Eliki fault segment, Gulf of Corinth, Greece, inferred from Holocene and Pleistocene terraces. J. Geol. Soc. Lond. 2004, 161, 81-92. [CrossRef]

48. Dermitzakis, M. Geological investigation on the Neogene of the Ierapetra area, Crete Island. Ann. Geol. Pays Hell. 1969, 21, 342-484. (In Greek)

49. Angelier, J.; Gigout, M. Sur les plates-formes marines et la neotectonique Quaternaires de la region d'Ierapetra (Crete, Grece). $C R$ Acad. Sci. Paris 1974, 278, 2103-2106. 
50. Tiberti, M.M.; Basili, R.; Vannoli, P. Ups and downs in western Crete (Hellenic subduction zone). Sci. Rep. 2014, 4, 5677. [CrossRef] [PubMed]

51. Theodoropoulos, D. Geological and Morphological observations in the area of Neapolis Vion. Ann. Geol. Pays Hellen. 1974, 25, 445-466.

52. Kelletat, D.; Kowalczyk, G.; Schroder, B.; Winter, K.P. A synoptic view on the neotectonic development of the Peloponnesian coastal region. Z. Dtsch. Geol. Ges. 1976, 127, 447-465. [CrossRef]

53. Lekkas, S.; Zambetakis, A.; Kapralos, E.; Mazarakis, K. Geological observations in Elafonissos. Bull. Geol. Soc. Greece 1988, XX, 67-82.

54. Kourampas, N. Plio-Quaternary Sedimentation and Geomorphology within an Active Fore-Arc: Messenia and Eastern Lakonia Peninsulae, Southern Peloponnese, Greece. Ph.D. Thesis, University of Edinburg, Edinburg, UK, 2001.

55. De Gelder, G.; Jara-Munoz, J.; Melnick, D.; Fernandez-Blanco, D.; Rouby, H.; Pedoja, K.; Husson, L.; Armijo, R.; Lacassin, R. How do sea-level curves influence modeled marine terrace sequences? Quat. Sci. Rev. 2020, 229, 106132. [CrossRef]

56. Karymbalis, E.; Chalkias, C.; Ferentinou, M.; Chalkias, G.; Magklara, M. Assessment of the Sensitivity of Salamina and Elafonissos islands to Sea-level Rise. J. Coast. Res. 2014, 70, 378-384. [CrossRef]

57. McClusky, S.; Balassanian, S.; Barka, A.; Demir, C.; Ergintav, S.; Georgiev, I.; Gurkan, O.; Hamburger, M.; Hurst, K.; Kahle, H.; et al. Global positioning system constraints on plate kinematics and dynamics in the eastern Mediterranean and Caucasus. J. Geophys. Res. Solid Earth 2000, 105, 5695-5719. [CrossRef]

58. Reilinger, R.; McClusky, S.; Vernant, P.; Lawrence, S.; Ergintav, S.; Cakmak, R.; Ozener, H.; Kadirov, F.; Guliev, I.; Stepanyan, R.; et al. GPS constraints on continental deformation in the Africa-Arabia-Eurasia continental collision zone and implications for the dynamics of plate interactions. J. Geophys. Res. Solid Earth 2006, 111, 26. [CrossRef]

59. Kahle, H.; Cocard, M.; Peter, Y.; Geiger, A.; Reilinger, R.; Barka, A.; Veis, G. GPS-derived strain rate field with the boundary zones of the Eurasian, African and Arabian Plates. J. Geophys. Res. 2000, 105, 23353-23370. [CrossRef]

60. Hollenstein, C.; Müller, M.D.; Geiger, A.; Kahle, H.G. Crustal motion and deformation in Greece from a decade of GPS measurements, 1993-2003. Tectonophysics 2008, 449, 17-40. [CrossRef]

61. Wortel, M.J.R.; Spakman, W. Subduction and slab detachment in the Mediterranean-Carpathian region. Science 2000, 290, 1910-1917. [CrossRef]

62. Papazachos, B.C.; Karakostas, V.G.; Papazachos, C.B.; Scordilis, E.M. The geometry of the Wadati-Benioff zone and lithospheric kinematics in the Hellenic arc. Tectonophysics 2000, 319, 275-300. [CrossRef]

63. Spakman, W.; Wortel, M.J.R.; Vlaar, N.J. The Hellenic subduction zone: A tomographic image and its geodynamic implications. Geophys. Res. Lett. 1988, 15, 60-63. [CrossRef]

64. Pe-Piper, G.; Piper, D.J.W. The Igneous Rocks of Greece: The Anatomy of an Orogen; Gebruder Borntraeger: Berlin, Germany, 2002; p. 288.

65. Faccenna, C.; Jolivet, L.; Piromallo, C.; Morelli, A. Subduction and the depth of convection in the Mediterranean mantle. J. Geophys. Res. 2003, 108, 2099. [CrossRef]

66. van Hinsbergen, D.J.J.; Hafkenscheid, E.; Spakman, W.; Meulenkamp, J.E.; Wortel, R. Nappe stacking resulting from subduction of oceanic and continental lithosphere below Greece. Geology 2005, 33, 325-328. [CrossRef]

67. Vött, A. Relative sea-level changes and regional tectonic evolution of seven coastal areas in NW Greece since the mid-Holocene. Quat. Sci. Rev. 2007, 26, 894-919. [CrossRef]

68. I.G.M.E. Geological Map of Greece (Scale 1:50,000) Sheet Neapolis-Ag. Nikolaos; Institute of Geology and Mineral Exploration of Greece: Athens, Greece, 1999.

69. Lekkas, S.; Alexopoulos, A.; Danamos, G. Neotectonic Map of Greece: Gythio, Neapolis, Elafonisos Sheets, Scale 1/100,000; Earthquake Planning and Protection Organization (EPPO) and the European Center on Prevention and Forecasting of Earthquakes (ECPFE): Athens, Greece, 1997.

70. Karymbalis, E.; Gaki-Papanastassiou, K.; Tsanakas, K.; Ferentinou, M. Geomorphology of the Pinios River delta, Greece. J. Maps 2016, 12, 12-21. [CrossRef]

71. Tsanakas, K.; Karymbalis, E.; Gaki-Papanastassiou, K.; Maroukian, H. Geomorphology of the Pieria Mtns, Northern Greece. J. Maps 2019, 15, 499-508. [CrossRef]

72. Lamothe, M. Luminescence dating of interglacial coastal depositional systems: Recent developments and future avenues of research. Quat. Sci. Rev. 2016, 146, 1-27. [CrossRef]

73. Murray, A.S.; Olley, J.M. Precision and accuracy in the optically stimulated luminescence dating of sedimentary quartz: A status review. Geochronometria 2002, 21, 1-16.

74. Tsodoulos, I.M.; Stamoulis, K.; Caputo, R.; Koukouvelas, I.; Chatzipetros, A.; Pavlides, S.; Gallousi, C.; Papachristodoulou, C.; Ioannides, K. Middle-Late Holocene earthquake history of the Gyrtoni Fault, Central Greece: Insight from optically stimulated luminescence (OSL) dating and paleoseismology. Tectonophysics 2016, 687, 14-27. [CrossRef]

75. Duller, G.A.T. Distinguishing quartz and feldspar in single grain luminescence measurements. Radiat. Meas. 2003, 37, 161-165. [CrossRef]

76. Duller, G.A.T. Single-grain optical dating of Quaternary sediments: Why aliquot size matters in luminescence dating. Boreas 2008, 37, 589-612. [CrossRef] 
77. Bøtter-Jensen, L.; Thomsen, K.J.; Jain, M. Review of optically stimulated luminescence (OSL) instrumental developments for retrospective dosimetry. Radiat. Meas. 2010, 45, 253-257. [CrossRef]

78. Murray, A.S.; Wintle, A.G. Luminescence dating of quartz using an improved single-aliquot regenerative-dose protocol. Radiat. Meas. 2000, 32, 57-73. [CrossRef]

79. Liritzis, I.; Stamoulis, K.; Papachristodoulou, C.; Ioannides, K. A re-evaluation of radiation dose-rate conversion factors. Mediterr. Archaeol. Archaeom. 2013, 13, 1-15.

80. Durcan, J.A.; King, G.E.; Duller, G.A.T. DRAC: Dose rate and age calculator for trapped charge dating. Quat. Geochronol. 2015, 28, 54-61. [CrossRef]

81. Chappell, J. Geology of coral terraces, Huon Peninsula, New Guinea: A study of Quaternary tectonic movements and sea-level changes. Geol. Soc. Am. Bull. 1974, 85, 553-570. [CrossRef]

82. Valensise, G.; Ward, S. Long-term uplift of the Santa Cruz coastline in response to repeated earthquakes along the San Andreas fault. Bull. Seism. Soc. Am. 1991, 81, 1694-1704.

83. Giunta, G.; Gueli, A.M.; Monaco, C.; Orioli, S.; Ristuccia, G.M.; Stella, G.; Troja, S.O. Middle-Late Pleistocene marine terraces and fault activity in the Sant'Agata di Militello coastal area (north-eastern Sicily). J. Geodyn. 2012, 55, 32-40. [CrossRef]

84. Papanastassiou, D.; Cundy, A.B.; Gaki-Papanastassiou, K.; Frogley, M.R.; Tsanakas, K.; Maroukian, H. The uplifted terraces of the Arkitsa region, NW Evoikos Gulf, Greece: A result of combined tectonic and volcanic processes? J Geol. 2014, 122, 397-410. [CrossRef]

85. Rabineau, M.; Berné, S.; Olivet, J.L.; Aslanian, D.; Guillocheau, F.; Joseph, P. Paleo sea levels reconsidered from direct observation of paleo-shoreline position during Glacial Maxima (for the last 500,000 yr). Earth Planet. Sci. Lett. 2006, 252, 119-137. [CrossRef]

86. Pedoja, K.; Husson, L.; Bezos, A.; Pastier, A.; Imran, A.M.; Arias-Ruiz, C.; Sarr, A.; Elliot, M.; Pons-Branchu, E.; Nexer, M.; et al On the long-lasting sequences of coral reef terraces from SE Sulawesi (Indonesia): Distribution, formation, and global significance. Quat. Sci. Rev. 2018, 188, 37-57. [CrossRef]

87. Yildirim, C.; Melnick, D.; Ballato, P.; Schildgen, T.F.; Echtler, H.; Erginal, A.E.; Kıyak, N.G.; Strecker, M.R. Differential uplift along the northern margin of the Central Anatolian Plateau: Inferences from marine terraces. Quat. Sci. Rev. 2013, 81, 12-28. [CrossRef]

88. Lisiecki, L.E.; Raymo, M.E. A Pliocene-Pleistocene stack of 57 globally distributed benthic $\delta 180$ records. Paleoceanography 2005, 20, PA1003. [CrossRef]

89. Caputo, R.; Bianca, M.; D'Onofrio, R. Ionian marine terraces of Southern Italy: Insights into the Quaternary tectonic evolution of the area. Tectonics 2010, 29, TC4005. [CrossRef]

90. Aitken, M.J. Thermoluminescence Dating; Academic Press: Orlando, FL, USA; London, UK, 1985; p. 351.

91. Prescott, J.R.; Hutton, J.T. Cosmic ray contribution to dose rates for luminescence and ESR dating: Large depths and long-term time variations. Radiat. Meas. 1994, 23, 497-500. [CrossRef]

92. Galbraith, R.F.; Roberts, R.G.; Laslett, G.M.; Yoshida, H.; Olley, J.M. Optical dating of single and multiple grains of quartz from Jinmium rock shelter, northern Australia: Part I, experimental design and statistical models. Archaeometry 1999, 41, 339-364. [CrossRef]

93. Gallup, C.D.; Edwards, R.L.; Johnson, R.G. The timing of high sea levels in the past 200,000 years. Science 1994, 263, 796-800. [CrossRef] [PubMed]

94. Kim, K.J.; Sutherland, R. Uplift rate and landscape development in southwest Fiordland, New Zealand, determined using 10Be and 26Al exposure dating of marine terraces. Geochim. Cosmochim. Acta 2004, 68, 2313-2319. [CrossRef]

95. Morewood, N.C.; Roberts, G.P. Lateral propagation of the surface trace of the South Alkyonides normal fault segment, central Greece: Its impact on models of fault growth and displacement-length relationships. J. Struc. Geol. 1999, 24, 3081-3084. [CrossRef]

96. Houghton, S.; Roberts, G.; Papanikolaou, I.; McArthur, J. New 234U-230Th coral dates from the western Gulf of Corinth: Implications for extensional tectonics. Geophys. Res. Lett. 2003, 30. [CrossRef]

97. Kowalczyk, G.; Winter, K.P.; Steinich, G.; Reisch, L. Jungpleistozane Strandterrassen in Siidost-Lakonien (Peloponnes, Griechenland). Schr. Geowiss. 1992, 1, 72.

98. Imbrie, J.; Hayes, J.D.; Martinson, D.G.; Maclntyre, A.; Mix, A.; Morley, J.J.; Pisias, N.G.; Prell, W.; Shackleton, N.J. The orbital theory of the Pleistocene climate: Support from a revised chronology of the marine $\delta^{18} \mathrm{O}$ record. In Milankovitch and Climate; Berger, A., Imbrie, J., Hayes, J.D., Kukla, G., Saltzman, B., Eds.; D. Reidel Publishing Company: Hingham, MA, USA, 1984; pp. 269-305. 